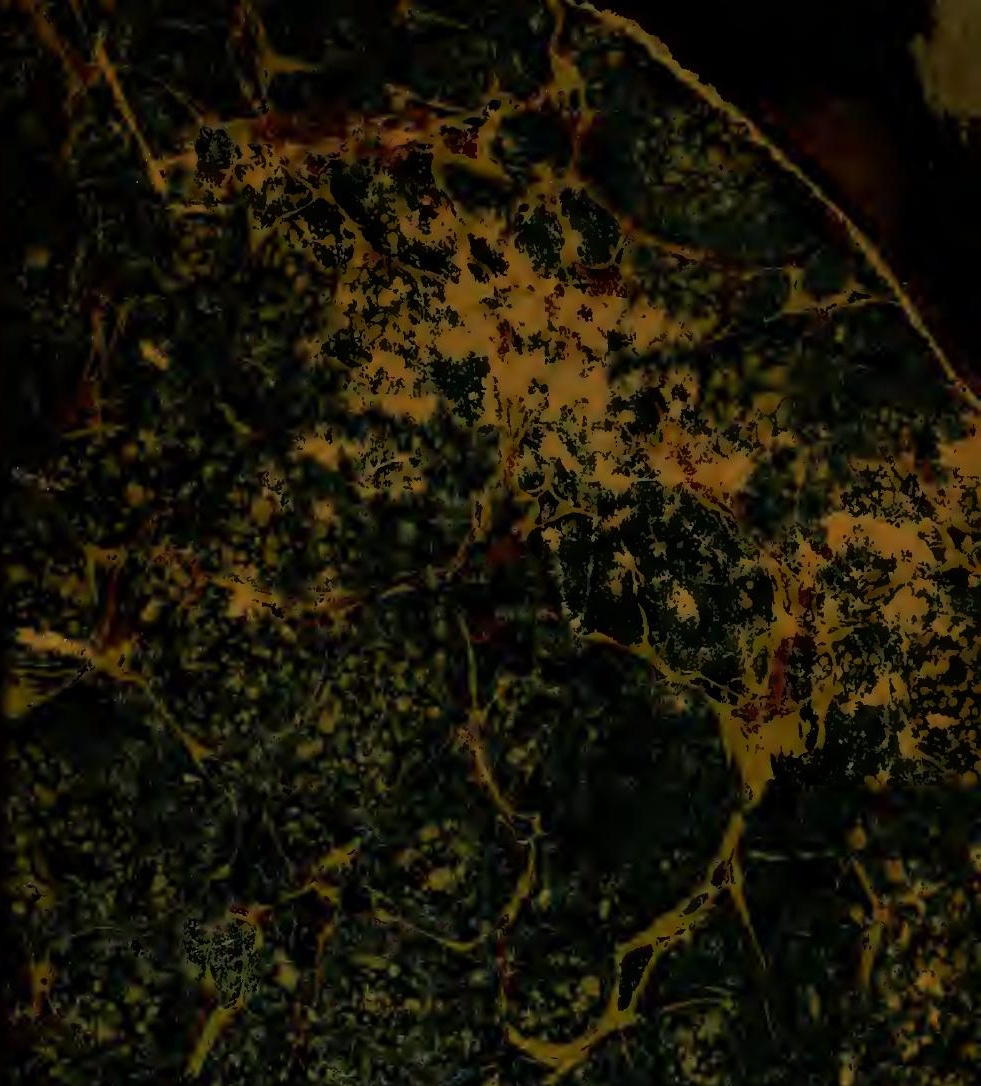

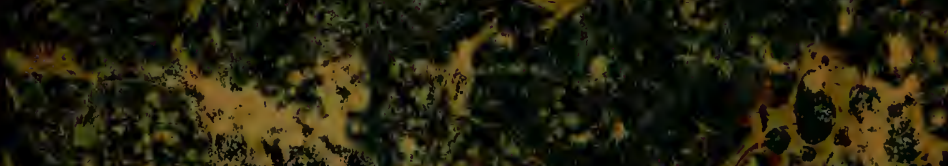

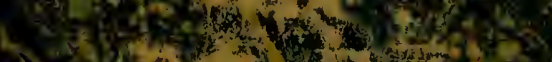

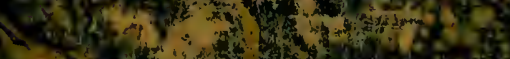

4.

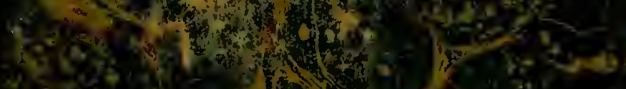

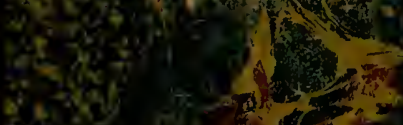
2. - An

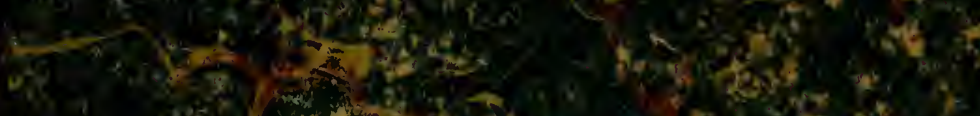
2.

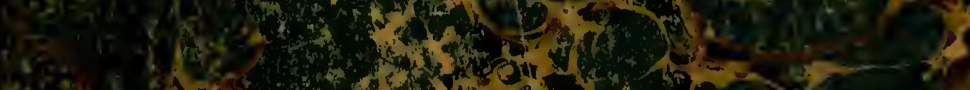

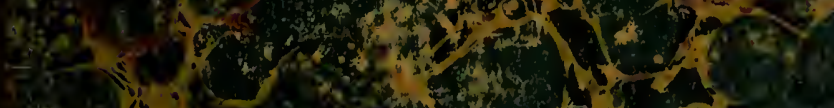

2.8. 2. 


\section{LIBRARY OF THE}

COOPER-HEWITT MUSEUM OF DESIGN

• SMITHSONIAN INSTITUTION •

Gift

Cooper Union Library 




Cntered, according to Act of Congress, in the year 1844, by HARPER \& BROTHERS,

In the Clerk's Office of the Southern District of New-Y'cris.

$$
\begin{gathered}
739 \\
\text { V } 531 .
\end{gathered}
$$

\section{2}
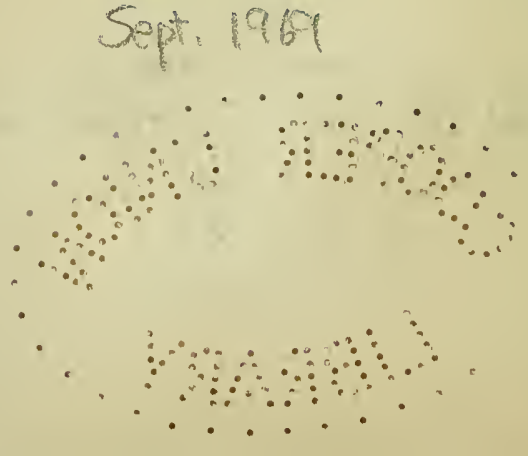


\section{A D VERTISEMENT.}

'The Spoon' is the first of a series of papers designed to elucidate the origin, history, and value of several primitive devices, which, from their apparent insignificance, have been overlooked by writers on the useful arts; but which have not been without their influence on the progress of civilization. As it was out of the question to treat every subject with the gravity due to historical research-to do so a writer must be the personification of melancholy herself-the idea was adopted of embracing them under the 'Transactions' of a Society, whose name should indicate their miscellaneous character, and relative value among literary merchandize. Small as this value may be, there are persons simple enough to suppose the annals of the shuttle and needle, of bellows and boilers, \&c. possess higher claims on the attention of the moralist, philosopher, and historian, than many dignified tomes of acknowledged history; for what are these, when divested of extraneous matters, but records of the club, sword and bayonet, the musket, cannon, and scaffold?

THE PUBLISHERS. 



\section{PR EF A CE.}

A TURKIsH shepherd tending his flocks in the vicinity of Adrianople, bethought of solacing himself with a few whiffs of tobacco. Seated on the ground, under the shade of a tree, he drew from a pouch his apparatus for striking fire, but found the piece of flint missing. He therefore arose, looked about for a stone, and at length picked up a pebble, which answered the purpose so well that he used it daily for a year or more. It came to pass that a Jewish pedlar one morning approached as the boor was lighting his pipe. The Israelite took a fancy to the stone, and bought it for a few aspers-soon after which, it shone the largest and brightest gem in the turban of Mahomet IV :-Now every reader of this book will either resemble the disciple of Moses or the Mahommedan keeper of sheep. It is true, diamonds are not concealed within the leaves; yet he who has wit to detect, aurum e stercore, gold from dirt-will certainly meet with something more than materials to light a cigar.

New-York, February, 1844. 



\section{INTRODUCTION :}

Embracing a Sketch of the Origin and Organization of tha Society of Chiffonniers.

\section{Courteous Reader :}

In the character of an author I beg leave to salute thee as my reader; and, as host of "The Globe," as my guest. Having for some time kept an establishment for the accommodation of travellers-that is, for supplying at moderate charges such conveniences and refreshments as are necessary to comfort and strengthen the body or outer man, I have lately been induced, indeed in a manner compelled, by the rage of competition, to add a new branch to the business; a department for providing various cates and delicious dainties to cheer and invigorate the spirit or inner man-to the end that both the mental and material palates of my patrons may be gratified at my table.

This, it is suspected, will become a general practice. As libraries are expelling decanters from steamers, sojourners at hotels will next require landlords to furnish literary as well as culinary food-books as well as butcher's meat; philosophical essays and fashionable novels as well as pasties and beef à la mode. A change is passing over the world, and none feel it more than those in my line. Temperance has already turned bar-rooms out of doors; while, 
from the efforts made by new doctors on diet, it is likely kitchens will soon have to follow. So far as I am concerned, the change will not be disagreeable, for I still prefer Horace to Kitchiner, and Tully to Mrs. Glasse. I can have no objection to imitate Phædo, who kept a victualing shop, and entertained those whom he fed; for like him I may peradventure have a Socrates for a boarder. May I hope, gentle guest, our acquaintance will be as agreeable to thyself as to me-that the fare to be set before thee will be to thy taste, and that I and my family may often have the prof-I mean the pleasure of thy company.

Ahem-It never was my wont to make excuses when my stock of viands was low; yet, sooth to say, the pantry is at present bare of fresh meats and of game. Vegetable and other watery aliments have been so much cried up in these parts, that old dealers in sirloins and haunches have been driven from the trade; some have taken stands in the fish-market, others opened stores for the sale of garden truck, and not a few have begun to vend "cookies and candies," which last, strange to say, are found the most profitable. All I can therefore promise thee on the present occasion is a simple dish, or rather a wholesome bowl of spoon-meat-un dejeuné à la cuiller. I pray thee let not thine anger kindle at this announcement, for, on my veracity and hopes of public favor, it is a pleasant and not an unsubstantial food-a rather thick, but still an agreeable, acidulous fluid-one in which thou wilt find (what Englishmen erroneously attribute to beer) both meat and drinkthough certainly not washing and mending, which Irishmen, it is said, formerly ascribed to their whiskey.

I Its appearance may not be enticing to "queasy" appetites, but I have seldom known a customer who, after once tasting it, did not lick the dish clean. Pray excuse me: I am oblivious in bringing into the parlor expressions belong- 
ing to the kitchen. But I scorn to take advantage of any one-to decoy customers by false colors; $i$. e. by hanging out signboards which promise what I cannot supply. Thou hast seen my signum on the title page, where it honestly indicates, as honest signs should do, the entertainment to be had within; and to convince thee of the liberal principles on which I am determined to build up my business, I ask not a doit for the meal of which thou art about to partakeall that is required of thee is to meet the small charge of the publisher for this "bill of fare." Having done thatthere is a seat-here comes thy food-now sit thee down, and in the language of mine ancient brethren of the spigot and spit, "much good may it do thee."

There is one thing it behooves me to say, since it will, I trust, assist in making our acquaintance more lasting than from a temporary visit it otherwise might be. People of my profession are natural judges of character. Without knowing how, we become practical physiognomists-comprehending at a glance a stranger's disposition, his station in society, and often the state of his purse-not that the latter excites my curiosity as it does that of unworthy members of the craft-men whose attentions are graduated by their ideas of the repletion or collapsion of a customer's pockets. Now there are traits in thy countenance of a cultivated and ingenuous mind-marks stamped by Nature on her favorite offspring. Hence it is not less my duty than my desire to make thy short stay with me agreeable.

It was formerly a custom of respectable hosts to entertain an esteemed guest during his first refection with pleasant stories, traditions, local news, or other matters; on which account, chiefly, inns or taverns became known as "houses of entertainment." Attached as I am to the good old ways of our forefathers, I will take this chair and relate some particulars which will not be distasteful to so 
amiable a spirit as thine. They will prepare thee for the company of a number of gentlemen, whom I hope to have the honor of introducing to thee, members of a society whose meetings are held once a week in my house. If I have not misjudged thy character, thou wilt be amused with their conversation; and wilt moreover learn the names of some new dishes, which, with their assistance, I hope shortly to serve to my customers.

I have here an abridged history of the association, drawn up by the secretary. It commences thus:

"The society was organized by a few plain individuals whose time was taken up during the day with the current occupations of life. Men of moderate capacities and attainments, they united to a little general knowledge a pretty large amount of ambition, for they determined not to be overlooked in the general herd of the living, and not to sink into instant oblivion at death. They had no idea of having their individualities amalgamated with the myriads travelling with them to the grave-like drops of rain in a shower, undistinguishable from each other while falling, and never to be identified afterwards. They therefore cast about for the means of making some noise in the world, or of so performing their parts on its theatre, that if they could not secure the applause conferred on first rate actors, they would try to avoid the silence of contempt, that attends the entrance of poor ones, and the momentary shrug conferred on the exit of quiet ones.

"Impressed with these views, they concluded to form themselves into some kind of literary or philosophical society, this appearing the most promising mode of acquiring notoriety. They hoped in this way to accomplish jointly what they could not do individually, viz. get up something in the shape of a воок, which should make them known while they lived, and remain a memorial of them after their 
decease. It signified little how poor the performance might be, or how unfit they were to perform it, for they were aware that the more incapable an author is the more likely he is sometimes to be remembered; his unfitness being the very cause of his notoriety. They instanced the case of $\mathrm{W}$. READ, an English baronet, who published a work on optics, and could neither write a line of it nor peruse one; or even tell when his book was upside down-a circumstance by which alone he is still remembered, and his name renewed in print.

"Then, as for the number of copies sold-should they be many or few-some stray ones would be almost sure to wander through a century, if not a longer period ; and suppose the leaves then distributed by grocers, as envelopes of tea, cheese, or soap; or pasted as linings in trunks; they might perchance call up some recollections of, or enquiries about, the authors. Nay, if a dozen copies only were printed, future bibliomaniacs would certainly treasure them up like Queen Anne's farthings-or like the twenty-six volumes of sermons by William Davy, a Devonshire clergyman, of the last century, of which the first and only edition consisted of fourteen copies. A bookworm prizes one of these as a treasure; and hence, the members of the proposed association hoped some bookworms of the twentieth century would cluck over a few impressions of their work, as brooding hens over their callow young.

"The first thing was to agree on a plan, as success would depend principally upon the wisdom with which it was drawn up, and the energy and prudence with which it was carried out. Several meetings were held, and numerous measures suggested. Mr. Delf thought it would not be amiss to run over a host of institutions already established. Perhaps, (said he,) by modifying or by joining one of them, our objects might be attained. The idea was 
acted on, but none were found to be precisely what was wanted. Mr. Digwell remarked, that it would not answer at all to unite with any. We are (he observed) men of ordinary abilities, of humble pretensions, and never can attain distinction among abler persons. Instead of seeking initiation into Lyceums, Academies, and other bodies of the learned, among whom we can only be hewers of wood and drawers of water, lighters of lamps and riddlers of ashes'helps,' not members of the family - we ought to establish ourselves on independent, unoccupied ground. Let us have a field of our own, however small it may be-one that borders on no other people's property. ['A pretty large field, that,' observed Dr. Swallow.] I beg pardon; I meant one so clearly defined, so well enclosed, that there might be no danger of us trespassing on our neighbor's grounds, or they hunting on ours.

"I am not prepared at this moment to say where such a field is, but I am persuaded it is to be had. One to which other associations have no claim-to which their 'tracks' do not lead. It would indeed be unworthy of us to attempt a location where the title might be disputed; and sure I am we could not start a new settlement in the vicinity of our predecessors without being abused as intruders, if not served with writs of ejectment.

"Look at the hosts of regular associations for the promotion of science in general, and others to extend its separate departments ; the world is full of them; they swarm every where. It is the same with literary societies: these are as common as 'Common Schools,' and excite about the same amount of interest. Academies of the fine arts, and institutions for agricultural and mechanic arts, abound in every village. Their name is legion. So it is with religious, moral, and active benevolent societies. The best, at any rate the most attractive, sites are all taken up-not a yard is left be- 

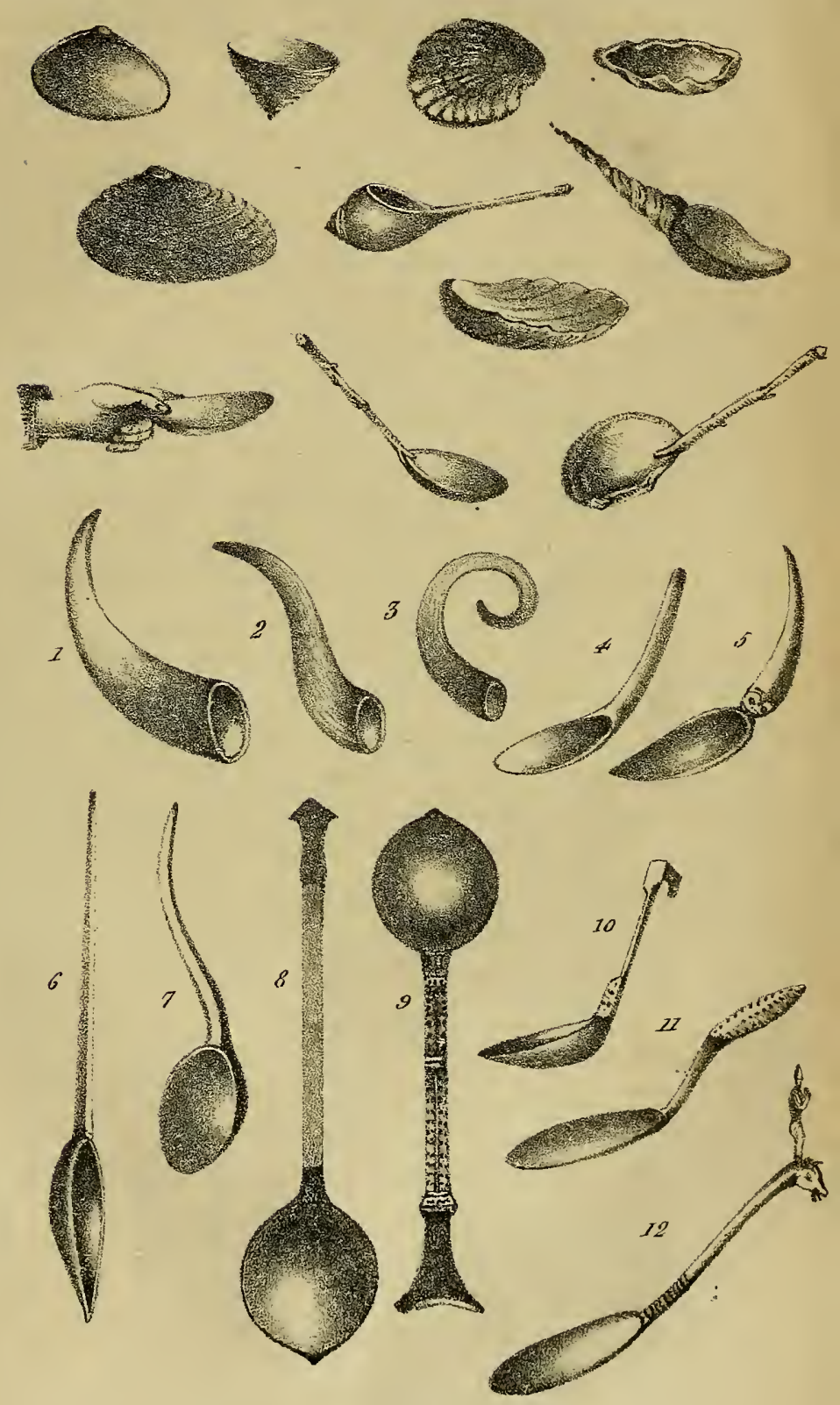

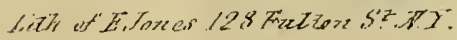



tween those cultivated by national institutes, and such as are covered by parish associations for the gratuitous distribution of soup."

[These sentiments were evidently approved, but as the evening was far advanced, a proposal was made to adjourn ; when Mr. Jacob Christener rose and begged leave to say a few words.]

"The gentleman is right, Mr. Chairman, and I thank him for so clearly opening the way for a motion I have to make. He has strengthened my convictions of its propriety, and given me the confidence I lacked to bring it forward. It seems to me, sir, the only plan open to us is the one I am about to propose, and if we don't lay hold of it, others will. It has hitherto been unthought of, but cannot long remain concealed. Reject it, and farewell to the happiness anticipated from our union while we live, and to the odor that is to exhale from our names after death. Adopt it, and this night we become the parents of a society whose auxiliaries will rise up in every land. In twelve months, we shall want a travelling agent, a foreign sec-"

[Here the speaker was interrupted with cries of "What is it?" "There's no time for a preface to-night!" "Order!" \&c.]

"Well, gentlemen, to be short, then : I propose that we organize ourselves into 'The Society of Literary and Scientific Chiffonniers.' [On this announcement, an explosion burst forth simultaneously from every mouth, except the speaker's, and some good humored remarks were exchanged. When the excitement had a little subsided, he continued :] I was prepared for this; I expected as much ; but hear me out, and then be as merry as you please. If a better plan be not brought forward-one equally original, and less open to objections-why, then it will be my turn to laugh. 
"Here have we been engaged this evening five mortal hours, without agreeing on the character of the proposed association, chiefly from the difficulty of steering clear of those already established. We admit the latter are too numerous to allow an additional one of the same kind any chance of success. Why, then, excite a competition we lack means to carry on? It would be folly to attempt it; besides, we are agreed that no modification of any old institution can meet our wants. Now, the plan I propose is derived from and indebted to none. It crowds on and interferes with none, but gives to all a wide berth. There is no danger of our ever being amalgamated with any. Our identity will be preserved, for none will be in a hurry to adopt our designation or infringe on our labors.

"Let us be candid, at least among ourselves. We are, then, philosophical mendicants. We have no property of our own-not a scrap-and we confess inability to originate any. Whatever we get must come from other people; hence, as members of established societies, we could not succeed, or even be respected, for we have nothing to command respect; and I risk little in saying, if we made application for admission, nine-tenths of us would be blackballed. As well expect Chambers of Commerce to offer scavengers seats and votes at their boards; or extensive dealers in dry goods to receive the owners of apple stands into their firms. There are but two ways to realize anything-honestly and roguishly; or, as the saying is, "by hook or by crook.' Now, as we disavow all ideas of hooks, (except the small and harmless ones by which chiffonniers raise moist matters into their baskets or bags, we must, to succeed in any other society, give value for the property we acquire-but this we cannot do-or receive it as almswhich we won't do. What, then, is left for us, but to pick up what others throw away? From my experience, gen- 
lemen, I assert there is more to be thus got, than you are aware of. With industry, we can acquire wealth-a local habitation and a name-wealth that none will dispute with us; for it will consist of a mass of minute matters, which, individually considered, the owners will be ashamed to claim. If we cannot deal in webs and wholesale packages of fresh goods, we shall become extensive jobbers in fragments of old goods.

"Pray, who can interfere with our ranging the bye-paths and alleys, the cellars and garrets of science, in search of lumber-to pick up, as it were, bits of rags, bones, and glass, with other small matters, which the wealthy throw out, and the proud step over? None. On the contrary, we can rake at our leisure the kennels, and stir up heaps of cinders and street sweepings, without let or hindrance; and, depend upon it, we shall every now and then meet with a godsend, (as our prototypes often do, in the shape of a silver spoon or fork, thrown out in slops by slipshod scullions.) Yes, industrious chiffonniers, we shall bring many rare and lost things to light-things singularly recherchécurious and useful as those found in historical and antiquarian collections. If' we are true to ourselves, the 'Cliffonniers' Repository' will soon equal in interest any other.

"Our labors will be pleasant; we can carry off what we fancy, and leave what is disagreeable. They will be profitable. Many a chiffonnier has purchased the house in front of which he once looked out for chiffons, has changed conditions with its owner, thrown off his professional garb and stepped into the parlor, lounged as a gentleman on his own sofa, and listened to the warblings of his daughters at the piano! And who knows, Mr. Chairman, but we shall do so too-shall hold our meetings in stately buildings now belonging to other societies, compete with the wealthy Nestors of knowledge in their own halls, and perhaps at last 
turn them out of their own doors! [Cries of 'Hear!" Hear!' interrupted the speaker.]

"Think, gentlemen, how interesting our meetings will be. When a member brings in his budget and displays his gatherings, who can sit still? Who can restrain his curiosity? Verily, not one of us! Then what original, erudite, and racy remarks will be made! Here, a speaker descanting on the value of spoons, or the history of gridirons; there, another relating the adventures of a stocking foot, which he proves once had a place in Queen Elizabeth's or Madame Maintenon's wardrobe. This member gives a lecture on the value of many simple and primitive devices which the world never thinks of; and that, shows the claims which the trammel and tinder-box have on the gratitude of mankind!

"Another word, and I have done: We shall have a jubilee once a year; for I propose that we offer a collection of chiffons at public sale, every spring or fall. Then will buyers of miscellanies crowd our marts, and bring us their wealth in exchange for our wares! We shall make a kind of Leipsic Fair of it! Gentlemen, our prospects are glorious; they brighten as we gaze at them. I feel animated by anticipations of success. I see that as Chiffonniers we shall ascend the rugged mount on which stands the temple of Fame, and get there before others who are now half way up. Bless us! what a welcome the old lady will give us to her abode! What a blast she will blow in honor of chiffonniering! -in praise of a new set of men who have cut a new path to her dwelling!"

[The speaker sat down amidst much acclamation.]

"The discussion here closed for the evening, and was resumed on the following one, when an extended and animated debate was kept up to a late hour. Various slight modifications of the plan suggested were brought forward. They 
will be understood from the style or title by which each speaker proposed to designate the body. The most striking were: 'Odds and Ends Association,' 'Literary Rag Society,' ' Scientific Scrap ditto,' ' Miscellany Club,' ' Chiffonniers' Institute,' 'Society for reviving the claims and preserving memorials of sundry Primitive Inventions,' 'Emporium of Philosophical Small Wares.' The general feeling settled on the fourth and fifth. At the first ballot, the votes stood equally in favor of the Miscellanarians and the Chiffonniers-but on the second, the street rovers and rag pickers were triumphant.

"The Chiffonniers admitted 'The Miscellany Club' would be a more respectable designation; and the Miscellanarians conceded that 'The Chiffonniers' Institute' was characteristic and select. By a subsequent and unanimous vote, the latter was changed to 'The Society of Literary and Scientific Chiffonniers,' as at first proposed.

"A constitution was next agreed on. It declares the objects of the society to be, the picking up of literary, philosophical, mechanical, or other fragments, from unusual or neglected sources, and to revive the claims of simple, and what are generally deemed insignificant, devices. It is the duty of each member to visit odd and out of the way places, open to him, in search of chiffons. Common subjects of discussion are excluded at the meetings. A paper on matches or walking-sticks would be applauded, while one on the strength or other properties of timber would be a signal for the author's expulsion. A communication on costume would be received perhaps with indifference, but if confined to a single article of apparel, or to a fragment of one, would be hailed with acclamation. A lecture on any regular manufacture, as glass making, iron founding, earthen ware, the furniture of a parlor or kitchen, \&c. would hardly : be admissible; but one on a bottle, or part of one, on a cal- 
dron, a pipkin, a broken chair, or a cheese grater, would rejoice the hearts of the mernbers. Every chiffonnier to prepare a paper or lecture on a chiffon, in his turn.

"At the first meeting under the constitution, the expressive apothegm 'Vive la Bagatelle' was selected as the Society's motto. The author of the plan adopted was chosen President, but as Mr. Christener persisted in declining the chair, to which he was entitled, the late Dr. Nathan Swallow was elected, though not by a unanimous vote. No other member possessed such varied qualifications. His experience with men and matters was extensive, for he had dabbled in almost every thing, but succeeded in few.

"Had been every thing by starts, but nothing long."

"How he came by his title is a vexed question, as he was never known to have studied medicine, nor to have dealt in drugs, except one which no longer holds a place in the pharmacopia. Alchemy was his favorite study, and he is saicl to have made a near approach to projection; i.e. to the composition of a powder which, thrown into certain ingredients, transmutes them to gold. Certain it is, he realized money by a secret of this kind, while others who tried it were ruined. One person of property lost his all in two years; and another was beggared in less time, and consigned, a hopeless maniac, to a lunatic asylun; but the history of modern as well as ancient alchemy is full of such things.

"He talked on all subjects, practical or theoretical, physical or metaphysical; on the properties of iron and whiskey, colors and calicoes, filial obedience and the philosopher's stone; on the evils of theatres, and the performance of crack actors. He occasionally performed Falstaff, and without stuffing, for he was what the French call chargé de cuisine. Columbus himself was not more embued with the spirit of adventure. Within a fortnight of first hearing the 
terms geognosy, hornblende, serpentine, trilobite, and madrepore, in a conversation between two geologists, he had a person at work labeling a basket of minerals; and getting the names of a dozen by heart, boldly proposed to undertake the survey of a state. An extraordinary chiffonnier, he dashed without hesitancy into every opeining where chiffons were likely to be had-he was not one of those who confine themselves to street sweepings, but was ever on the qui vire for wholesale speculations. Dryden certainly must have dreamt of him when describing Buckingham, for

He was often in the course of one revolving moon,

Author, aclor, artist, cook, chemist, and buffoon :

And in another month' as many more.

"Rich in Apician lore, he could enumerate the famous dishes of old, from those placed on the table of Heliogabalus to Spartan broth and Athenian porridge, and could name the ingredients of all. In modern cookery, he was more at home; nothing escaped his observation, and but little his palate. His taste was equal to Pollio's ; his knowledge of the mysteries of the kitchen surpassed that of M. Beaujeu. See him take his seat at a supper party; watch him draw a laden dish towards him, and you would shudder from a dread that his eyes were about to drop into his plate-as if attached like those of the chameleon to the ends of flexible tubes, so fearfully did they advance and recede. He was at one time known as 'Spoonie,' and 'Eating Nat,' for he had an appetite equal to Galba's-a stomach capacious as that of Vitellius. His spoon, and he had one for his exclusive use, might apply to him, with a slight alteration, an epigram by Boileau:

Here lies my owner, and heaven knows,

Not less for mine than his repose.

"An excellent representative of the god of raillery and ridicule-that is, if Momus was a short and squab fellow 
of forty, with a droll leer, a shambling gait, and a touch of Silenus or Bacchus about him. Exceedingly facetious, the Doctor told stories equal to Matthews or Hackett, and rivaled Braham in singing. He was full of first rate though second hand wit. His physiognomy was prepossessing, though his friends used to joke him about a devil lurking in his eye, which, they said, appeared sly as Sancho's, and mischievous as the solitary one in Ichabod Crane's nag.

"His knowledge was said by his friends to have been universal. In science, an Arago; in philosophy, a Newton; in chemistry, a Farraday or Berzelius; in general knowledge, a Crichton. Well versed in Thaumaturgy, he certainly could beat conjurers at their own weapons. An adept in Metoposcopy, he saw at once the various points in human character, and by some mesmeric influence could always open a communication between himself and those in whose affairs he wished to take an interest.

"All great men have their enemies, and Doctor Swallow was not without his. He had to pay the usual penalty exacted by envious detractors. These insisted that he was a literary Bombastes, in veracity a Mandeville, in morals a Mephistopheles, in scheming a Machiavel, and in every thing except humbugging a humbug. A retailer of other men's ideas, which (said they) he claimed as his own, and, like all liars, often forgot himself and claimed them in the presence of those from whom he received them-that his life was a lie. There is little doubt, that both parties were wrong. He never was the angel one made him, nor the devil the other called him; but, whatever he was, he was made President of the Society; and, all things considered, it was thought a better selection could not have been made; for, as an old chiffonnier, he had picked up more chiffons, and knew how to make more of them, than any other artist who lived by the hook. 
"Popular with most of the members, nearly all consulted him on subjects they brought forward. Ever ready to give advice, and seldom more pleased than when asked for it. Though he never wrote a paper but one, and of the authorship of that some doubts have been raised, he was a judge of what would 'take;' or, what often amounts to the same thing, he had that reputation.

"When conducted to the chair, he rose with smiles playing round his lips and satisfaction sparkling in his eyes, and thus commenced his opening address : Gentlemen, I.... I know not how to thank you for this honor. I....I....d-n it, I cannot make a formal speech-I never could-unless I had it by heart. I tried once before at extempore, but it was no go ; after getting rid of a few sentences, a kind of mental and physical lock-jaw seized me, and there I stoodmy mouth wide open, and without the power to close it, or to call to mind what I meant to say. It was said I stood grinning like a Barbary ape, and in my efforts to articulate might have stood longer, if Medlar had not pulled me down by the skirt, while saying loud enough (hang him) for half the room to hear, 'don't make an ass of yourself, Nat.' Gentlemen, that man is now here, and I never see him without thinking of the predicament I was in, and the ugly epithet he gave me. I cannot go on unless he goes out, and I am not sure even then. But, gentlemen, if I cannot thank you as I'd like to, I can treat you to something better-something to eat. Will not a member move an adjournment to my house, where we can discuss matters more at ease, and amuse ourselves at intervals with a cold cut and a drop of "- [Ere the proposition was finished, the meeting adjourned amidst cries of 'Bravo!' 'Excellent!' 'A first rate speech, that, Doctor!']

"Rëassembled at his dwelling, the party partook of a substantial supper, during which a curious conversation 
arose on variety of tastes for food. Mr. Milder, an amiable and highly intelligent young man, but rather odd in some of his views, thought it artificial; others, with the Doctor, contended that it was natural. Nature, it was said, never designed men to live on one kind of food; if she had, she would not have furnished them with so many. She moreover produces no one in sufficient quantities to supersede all others, nor has she distributed any one over the whole earth. That's true, observed the Doctor; if we were designed to have but one dish, as pork, beef, mutton, or turkey, bread, cabbage, potatoes, or yams, I should like to know where enough is to come from? The case is different with drink. Water may be the natural beverage of animals and men, for it is every where, and every where abundant; but not so with either animal or vegetable food. It was further observed by the advocates for variety, that we might as well read only one book as eat of one dish; for if material palates are originally moulded after one pattern, so are literary ones. But no, said they; Nature has made both to vary as much as the minds and persons or faces of men. The Doctor thought if men had but one dish for the body and another for the mind, it would save a world of trouble to booksellers and keepers of eating houses; yet, even with those people, he was sure things were better as they are, because, said he, different tastes bring into action diverse talents, and so give employment to hosts of writers, and, what is better, to swarms of cooks. It is therefore right that what suits one stomach should not be the thing to tickle all others. Here is my friend, Sam Tortiller, imagines a connection between the bent of man's genius and his favorite food; as if by knowing the general course of a person's studies one could tell what he craves for his dinner, and vice versa. I don't believe a word of it. A writer on morals may love pork, and an author of romances abhor 
it; but, to my knowledge, all pork eaters are not righteous men, nor those who let pigs alone composers of fiction. Professor Freeling often digests turkey, but it's not every chemist who can afford to put that into his digester. Then there is Finelli, a lover of shell fish-but what then?-if the lady that poets call the Genius of Song sometimes visits an oyster cellar, she does not confine her favors to those who either chew or eschew clams, crabs, and lobsters. Mr. Milder, let me help you to a slice of this ham; I believe you have not tasted it."

"Not any for me; I never eat any, Mr. President."

"Not eat ham! Why, you are neither a Jew nor a Turk, I hope, to abominate those glorious animals that supply us with the richest of all relishes?"

"No; but I prefer hams from China, if I must eat any."

"O! O! I thought you knew what's good! Well! I can't say this fine fellow ever ran through the streets of Canton; but, is the difference of flavor between your oriental favorites and ours very sensible?"

"Very."

"Ah! I must get my friend, Captain Drinker, to bring over a Chinaman grunter, or a few hams; but, will these not spoil on the voyage?"

"No danger of that. The fact is, sir, I am not a consumer of animal food; the joints I allude too are vegetable ones. They are described by $\mathrm{L}_{\mathrm{a}}$ Compte and other travellers."

"You are joking, (observed the Doctor, inquiringly;) Sam, here, says you are a terrible bore that way!"

"Not at all, (replied Mr. Milder;) I almost hope to see the day when no other hams will be used. You have heard of wooden ones?"

"Yes! Carved blocks of wood, so neatly sewed up in hog skins, as to deceive the eyes of the lieenest pork butch- 
ers! Yes; I have read of people boiling them, but I never heard of any having been eaten."

"True; but even that is not so unlikely as you seem to think.".

"I pray heaven, (said the Doctor,) the practice may never become general; the chine of a two year old shote is with me a favorite dish. What reason have you for supposing it ever will, Mr. Milder?"

"Why, sir, you of course know that a few years ago, a German philosopher discovered the nutritious elements of wheaten bread in wooden meal-that he made wholsome cakes out of pine boards, and supported his "wife and five children for seven weeks on dumplings kneaded of dough formed of fine sawdust and water. The paste, it is said, rose without leaven, and when cooked was really deliciousespecially so, when lubricated with molasses, or sprinkled with the essence of sugar, extracted by Braçonnot from old rags and scrap paper. Now, an ingenious friend of mine has been engaged on a somewhat analagous subject for the last twelve months, and, from an experiment I witnessed yesterday, I have no hesitation in avowing my confidence in his assertion that he will shortly produce good palatable pork out of whitewood, and well seasoned hams from red cedar."

[Much laughter, during which the Doctor observed, in a suppressed voice, to the gentleman at his right, "Sam, this fellow is a devil of a quiz; I cannot believe he is serious, and yet what a solemn phiz he puts on."]

"Now, sir, (continued Mr. Milder,) where is there a man of feeling who would not rejoice at the success of my friend, in attempting to change the world from a shambles for gratifying the carnivorous appetites of our species-a slaughter house constantly flooded with gore and vibrating with the shrieks of expiring victims? For my part, sir, I never 
see a fernale cutting up raw flesh, her hands smeared with blood-now killing, plucking, embowelling, and at last, with perfect nonchalance, transfixing innocent fowls or sucking pigs on the spit, without shuddering at the disgusting employment-at the horrible effects of indulging unnatural appetites! $\mathrm{O}$ ! how would the spirit of humanity exult at the abolition of animal diet-or even at the general introduction of vegetable hams! These would be a consummation in morals and science devoutly to be wished-to be prayed for; all Nature, sir, would rejoice at their manufactureat any rate, sir, you will admit, all PIGs would-and well they might, as they would (to use a vulgar expression) then save their own bacon! Yes! Their days of mourning would then be over.

"And why should they not save it, sir, as well as we preserve ours? Has not a pig organs, dimensions, feelings, passions, affections? If struck, does it not cry? If wounded, does it not bleed? If imprisoned and in bonds, does it not struggle to be free? If driven to the shambles, does it not refuse to go? When slain, does it not suffer the pangs of death? In one word, sir, is not life as precious to pigs as to any of us? And would they not have cause to rejoice were they and their offspring no longer murdered ere living out half their days? Millions are slain in their infancy, and their parents in the vigor of life! Upwards of a century ago, not less than 52,500 sucking innocents were annually immolated in London alone!

Lovely buds-their mother's pride!

[Here, as at every other pause made by the speaker, excessive laughter broke out afresh; but, unembarrassed, he continued:]

" There is something else, sir, in connection with this subject, which every lover of his country should deplore. Slavery is an unmitigated evil, and we are taught to admire 
the free States for shaking the incubus off; it is, however, a melancholy fact, that the citizens of what is called one of the most enlightened and liberal, are carrying to a hor rible extent, a system almost equally atrocious. As if res gretting their lost dominion over negroes, they seem deter mined to be revenged a hundred fold upon a race, between which and ours Blumenbach, in his remarks on varieties of complexion, has traced many analngies. Yes! The capi tal city of Ohio is rapidly rising into power, on the bodies of slaughtered swine! She is already known as 'The Emporium of Pork' -a designation which wicked Nineveh or more wicked Gomorrah would have shrunk from. Her merchandise is flesh. Her bulletins are occupied with its sales, and as the market price rises and falls, so does the value of her real estate. Her merchants are butchers; her staple is stearine; her palaces are built with the price of blood, and illumined at night with the fat of ber slain! All her lamps are replenished with lard! Like Babylon, 'seated on many waters, and drunken with blood,' so reclines Cincinnati, on a larger stream than the Euphrates, clothed in scarlet, and proudly calling herself 'Queen of the West!' But let her beware-for, depend upon it, sir, vengeance will not sleep forever; and when pigs get their rights, she will meet her deserts!"

[On Mr. Milder concluding his remarks, a shout of laughter arose that shook both floor and table. Some held their sides, and groaned with pain; others screeched as they, ever and anon, glanced at the imperturbable gravity of Mr. M. and the woful appearance of the President's face.]

But, indulgent guest, I am trespassing too much on thy patience. I will therefore lay aside, for the present, this account of the Society, and the rather since the author presses hard on the late President. They never were 
friendly. The Doctor, like other men, had his faults; but he had good qualities as well. Peace to his ashes! He was one of my best customers in one respect though not in another; for he never was in a hurry to wipe out his scores, and, to speak truth, some he never wiped out. When my turn came round for a paper, I consulted him for a subject, and submitted to him what I wrote. Desirous of not dis-s gracing my former profession of schoolmaster, I took parti-s cular pains; but the subject was new, and embarrassed me much. When I left the choice to him, I little imagined he would take a knife from the table and insist that $i t$ should be my text. However, I made out tolerably well; though he was sparing of praise. He was, in fact, not altogether pleased with my "Adventures of a Carving Knife;" but he made ample amends on another occasion, as will soon be perceived.

My next attempt was a higher flight-a composition balf dramatic. There were passages in it of tragic interest : at least, $I$ thought so. The subject-an ancient pincushion, brought over in the Mayflower. I had a presentiment that I should take the Doctor by surprise-snatch him up, as by a hurricane, into the regions of romance, and extort his praise ere he had time to descend and recover his self-possession. And, sure enough, something even more than this took place.

By appointment, I met him at his own house. He was in a happy mood, having just risen from dinner. We retired to the parlor, and I handed lim the MS. Drawing his arm-chair in front of the fire, and desiring me to take another, he made a remark about the high price of beef, and commenced reading the first paragraph; but he made such murdering work of the sense, running one sentence hall way into another, and then stopping as if brought up by a period, that I wriggled in the chair, and felt my viscera 
squirming like eels in a bag. I stopped him to explain, but he ascribed every thing to what he called my illegible hand. I proposed to read it myself. To this, he consented; and, for the benefit of light, I stepped to the window, some distance behind him; a circumstance which increased my confidence, and left him free to enter into the spirit of the story, unembarrassed with external interruptions.

I had not got through the first chapter before he gave utterance to some short but flattering expressions. They encouraged me wonderfully, and ere the second was finished became more frequent; the words "rich!" "capital!" dropped from him several times. I felt elated, and went on trippingly to the end-borne along by the kindness of his manner, and quite lifted up with the confidence of having fairly gained his approbation. The reading did not occupy over fifteen minutes; and, when finished, I remained standing, ready, with pencil in hand, to make such corrections and alterations as he might suggest. He seemed to be balancing the merits of different parts; for he said, as if to himself, "that was overdone ;" "the other excellent ;" "capital!" He resembled the gentleman mentioned by Horace,

Who long imagin'd that he heard the tone

Of deep Tragedians on an empty stage,

And sat applauding, in ecstatic rage.

My feelings quickly overcame my politeness, and I cried "Come, Doctor, what is the sentence? Life or death?" (I had heard enough to know what it would be.) As I said this, I resumed my seat beside him, and thanked him for the kind attention he had given to the humble performance; but I had scarcely finished the last word ere my old friend gave a memorable proof of the intense interest he had taken in the story-of the fine sensibilities of his nature, and the depth of his feelings. Now, Sir Guest, what think you he did? Perbaps you say: 'I suppose, Mr. Westman, his 
Plate?

Romarz

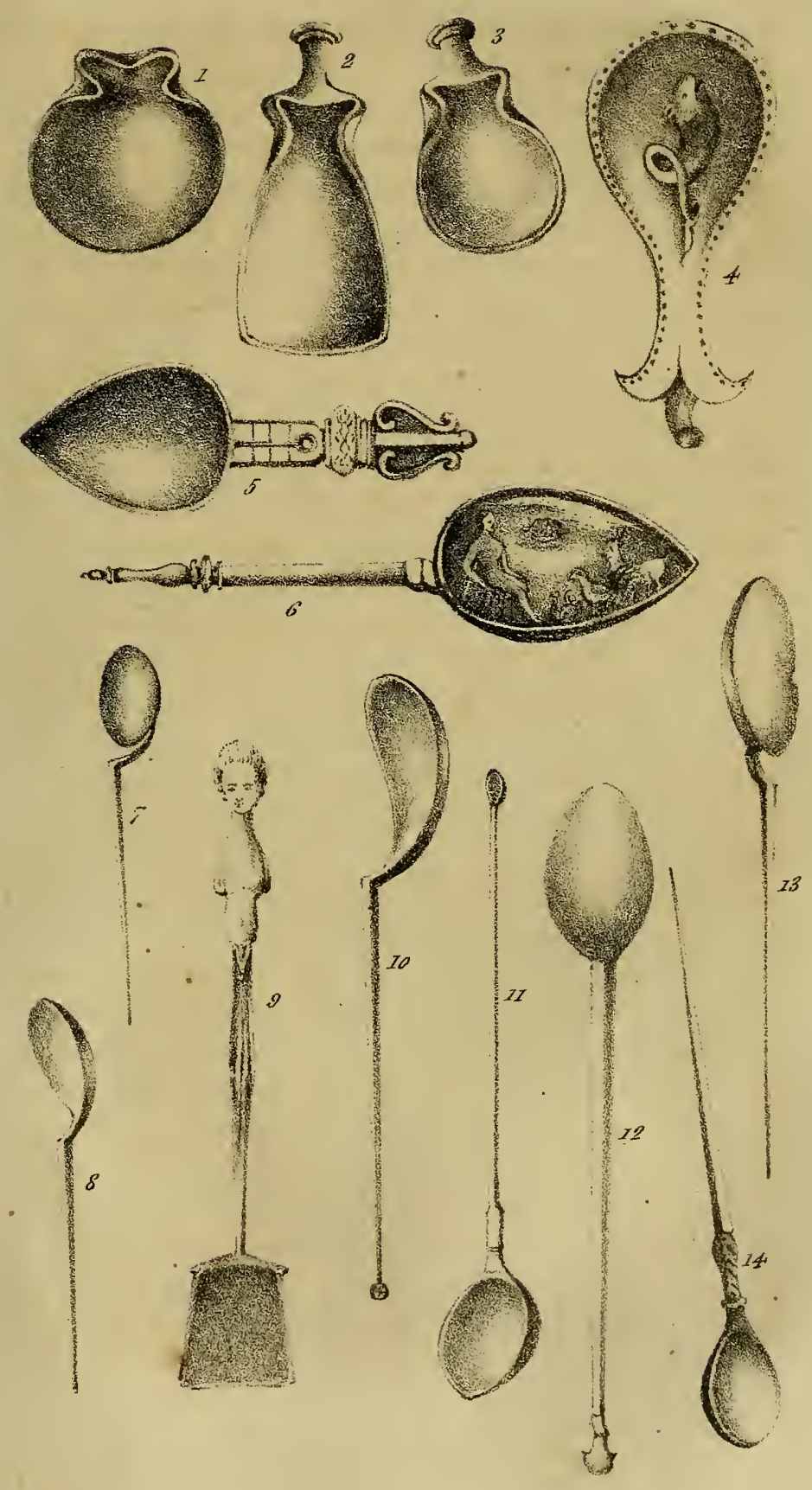



cheeks were streaming with tears-his passions, excited by the incidents of the story, had not recovered their natural tone! Or, did he spring from his seat and embrace the magician, who had such power to enchant him? Either would have been very natural.'

He did neither, sir; he was unable to rise.

'Indeed! Why, what was the matter?'

His mental and bodily powers were prostrated.

'What do you mean?'

He was dead! th-

'Dead! did you say, Mr. Westman?'

On my conscience, yes sir ; that is, he was, as the saying goes, dead asleep! As for tears, his cheeks were as free from them as the back of my hand, and his face calm as an infant's reposing on its mother's breast.

'You really surprise me!'

I was astonished myself, sir.

'And how did you act on making this strange discovery?'

I don't exactly know what I did, sir-nor what I thought -nor how I felt. I was paralyzed-deprived of the powers of speech and motion. My respiration was thick, and at last suspended. I believe I sat gazing on him five minutes without breathing or moving a muscle, except those by which the lower jaw is dropped to its farthest extent, and such as push the eyes out of the head. There was no mistake about his slumbers; to satisfy myself that they were genuine, I remember stretching my face towards his till both were nearly in contact. His mouth was wide open, and I had a full view of the horrible cavern within. What I suffered, ere I had power to leave my seat, was dreadful. Impalement could hardly, I should think, surpass it. When at last I rose and stepped in front of him, heaven forgive me, for, though I say it myself, a quieter man does not breathe, I felt as much inclined to push the end of my cane 
down his gullet as ever I had to send any thing pleasant down my own.

On second thoughts, I took my hat, put the MS. in my pocket, and walked softly to the door of the room; when I heard him mutter something about "Betty......sauce rich; veal......overdone ; rabbits......excellent." The brute, sirpardon the uncivil word-was dreaming about his dinner; but that was not all, nor the worst; for it was now clear he had fallen asleep almost as soon as he sat down, and the expressions of approbation which I had foolishly taken to myself were in reality compliments to Betty's skill in roasting and boiling! When this truth flashed on my mind, I felt keenly-my wrath rose, and Satan strongly urged me back to take leave of him by no gentle shake of his person or tweak of his proboscis-but either my good genius or his own interfered, and I hastened out of the house, without meeting one of the family. I am ashamed to say, I felt very unwell during the rest of the day, being greatly more affected than a sensible man should have been; but our feelings are not in our power.

I mentioned the circumstance to a few members the same evening, and learned the Doctor had been in gay company all the morning, and was certainly half drunk at the time of my interview with him. I certainly did notice something strange in him, but my mind was wholly absorbed on the paper. We were anxious to know how he would face the matter out; for no one believed he would for a moment acknowledge being asleep. Within a few days, Medlar, Pickwell, and I, met him in the street; when,-would you believe it?-without the slightest indication of embarrassment, he began the following colloquy:

'Neighbor Westman, further reflection has convinced me your last paper will never do. It will gain you neither credit with the members nor custom from their friends.' 
Further reflection, did you say, Doctor!

'There's nothing in it, believe me, (said he,) neither life-'

Rather nettled, I abruptly asked what he wanted in it.

'I'll tell you what I don't want-(he replied;) a tale dull and monotonous from beginning to end-one without a grain of piquancy in it-flat and distasteful as buckwheat cakes without salt or sauce.'

Now I thought I had done better than could have been expected; but stop, did you hear a word of-

' Expected! (he cried out, as if wanting to hear nothing more;) I expect, and so will the members, something like the spices and pickles at your ordinaries, and which you know full well often help an insipid dish down. The paper has but one quality that can render it of any service.'

What may that be?

'It might serve on occasion as a soporific.'

I believe I colored at this, and said sharply, Yes, I understand. It composed you to sleep quick enough—or something else did.

'No! not asleep; (said he, unabashed, as with a face of flint-absolutely staggering me with the audacious falsehood;) I remember feeling a little drowsy.'

Indeed! Do you recollect anything else?

'No! nothing particular-ex-except that my strictures were perhaps too severe; but I did not wish to mislead you by being less pointed.'

Your strictures, eh! Why, you made none, and for the best of reasons! Look ye, Doctor, you may, for aught I know, be able to catch authors napping when you're awake, but not when you're actually snoring. I've seen further into your head than you imagine.

Mr. Westman, (said he, in a bristling manner, I hope you don't mean to-to-t-t-t-'

Yes, I do! and what's more Doctor, I felt so confoundedly queer that $I$ had some difficulty in refraining from - 
"From what ?"

Never mind; I've got over it now; but you don't see another paper of mine, I promise you, unless you will go through it before dinner. "Further reflection," as you say, has convinced me the last is yet defective. I'll revise, and we'll read it some evening.

'Better put it in the fire, some morning, (he said, resentfully, as if caught in an unpleasant dilemma, and determined to get out with a bold face; then assuming a patronizing tone, added:) Believe me, neighbor, you, and others I wot of, will never succeed in life till you let scribbling alone.'

Then, Doctor, let me tell you tha-

'Peace, (he interrupted,) I pray you, peace! I know you, and Medlar, and Fribble, and Delever, well. Your talents are good of their kind, and may be useful in their place.

In their place! Where is that?

'In the kitchen! Confne your energies to your proper vocations, and you may do well. Stick to your fires and fuel, your andirons and hearths, spits and bellows, pots and pans, knives and forks-to your ladles and spoons-to-'

Enough! Enough! Egad, Doctor, you are right this time! (I exclaimed.) Yes, we will! We'll write papers on all of them; and I'll begin myself with THE spoon.

On hearing this, he gazed intently on my face, and, as he turned on his heel, whispered in my ear, "Habbakuk, thou hast been handling thy decanters this morning!"

I have no more to add, except to appeal, courteous: reader, to thy judgment. Let me, therefore, entreat thee not to peruse the following pages directly after dinner, lest Morpheus make his appearance, and thou shouldst sin, like the President of the Chiffonnier Society, by ascribing the imp's visit to

HAB'K O. WESTMAN. 


\section{The $\mathfrak{s p o o n}$}

\section{ANOIENT AND MODERN.}

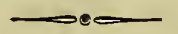

\section{CHAPTER I.}

Singular Subjects chosen by Authors-The Spoon, a popular and fertile one-Sancho Panza, a Spoonmaker-Influence of this Profession on his Adventures-Ingenuity of CervantesPedro Garcia's Purse-Selection of the Spoon for a Theme, an Indication of Taste-One of the first things wanted on coming into the world, and last parted with ere going out-Its Domestic and Moral Influence-Ancient Fracas with Hot Broth.

Singular are the subjects on which authors have written: as Lucian on a fly, Apuleius on the ass, Virgil on a gnat, and Homer on a pitched battle between some frogs and mice. One writer is sublime on a flea, another on the north wind, and a third on nothing. Here, one expatiates on the social pipe; and there, goes a royal counterblast against tobacco. Pope has a poem on a lock of hair, Gray wrote lines on a cat, Prior on the ladle, and Cowper on the sofa. 
Tasso spun out twelve cantos on a bucket, and John Heywood, in Henry the Eighth's time, wrote seventy-seven chapters on cobwebs and spiders.

The merry Dean of St. Patrick's wrote an essay on a broomstick; and some reviewer of a late work on hydraulics thinks the author could readily compose a homily on pump handles, or a series of meditations on cistern hooks. A fig for such subjects, and those who discuss them. A person's taste is seen in what he writes on, as well as in what flows from his pen; and small must be the brains that think on such things. Every one knows Swift's head was worn out when kind Nature led him to muse on the stump of a besom-an emblem of himself. As there was always something of the wizard about him, he naturally selected the same hobby that accommodates witches in their evening excursions. As for the other gentleman, he must be a dry soul indeed, since he could hit upon nothing but water, about which to fill up a book-or some rickety machines to get at it.

Commend us to something better than either; and on the present occasion to that which daily inspired the reverend wit, and at which it is very certain every writer on water-works has labored oftener than at any pump gearing-videlicit, A spoos. Why, there's life in the sound! To the hungry and poor and rich, it conjures up visions of pleasure. Its very picture moves the salivary glands into action, and sets the lickerish muscles agog, while thoughts of the good things with which it often is laden make 
mendicants draw in their breath and thrust out their lips, as if about to salute it!

What gentleman cares for a broom, or a cistern pole, except to kick them out of his way, as a fat neighbor of ours did yesterday? But for a spoon, ah! how eagerly he seized it at dinner! Like the hand of a friend for whom he had long anxiously waited, and from whom he could hardly be prevailed on to part.

As a novel and a popular subject, the spoon is unrivaled-as a fertile one, its equal never rose in the brains of Will Shakespeare or John Baptiste Moliere; and that is strange too, seeing the implement so often entered their heads. A Spanish writer of the sixteenth century, however, did not let it escape him. His wanderings through various countries, and in indifferent circumstances, made him too keenly alive to its value to forget or neglect it. He has immortalized himself by recording the adventures of a spoonmaker, in an inimitable piece of biography.

'Indeed! (exclaims some reader.) Pray, of whom do you speak? Who was this author, and who the mechanic he snatched from oblivion?'

Strange that at this day such a question should be asked! But, Miguel de Cervantes Saavedra was the writer, and Sancho Panza the artist.

'Sancho Panza! The short and fat husband of Tereza-the Governor of Barrataria-he whose simplicity and shrewdness, jokes and proverbs, were so pleasant; and whose witty conceits fell from him as thick as drops in a shower-a maker of spoons ?' 
To be sure he was! And it was from this circumstance he became so expert in handling them, and which led him to prefer olla-podridas, stews, and hashes of cow beef and onions, to Milan godwits, Roman pheasants, geese of Lavajos, and other kickshaws, which Doctor Pedro Rezio Aquero de Tirteafuera and the steward talked about. Not that Sancho loved good eating more than other people, but he naturally enough preferred those kinds of food which were fluid, in the conveyance of which to his mouth he had become quite familiar from his previous professions and habits.

Cervantes, to elucidate the association of ideas and the force of early impressions, wittily concealed this employment of Sancho's, and left it till the knight was condemned by him of the 'White Moon' to refrain for a whole year from using a sword, or going in quest of adventures. Then the truth unexpectedly appears. Quixote proposed to pass the time in pastoral pursuits. ' $O$, Sancho! said he; we will turn shepherds for the time I must live retired. I will buy sheep and all necessary materials. We will range the mountains, the woods, and the meadows-singing here and complaining there-drinking the liquid crystal of the fountains, of the limpid brooks, and the mighty rivers. The oaks, with a plentiful hand, shall give their sweetest fruit-the trunks of the hardest cork-trees shall afford us seats, the willows shade, and the roses scent. The spacious meadows shall yield us carpets of a thousand colors-the air, clear and pure, shall supply breath, 
the moon and stars afford light, mangre the darkness of night-singing shall furnish pleasure, and complaining yield delight! Heaven be my aid! What a life shall we lead, friend Sancho! What a world of bagpipes shall we hear! What pipes of Zamora! What tambourets and rebecks!'

' Before God, quoth Sancho, this kind of life squares with me exactly; and no sooner will the Bachelor Sampson Carrasco, and Master Nicholas the barber, have well seen it, but they will have a mind to follow, and turn shepherds with us ; and God grant that the priest have not an inclination to make one in the fold; he is of so gay a temper, and such a lover of mirth!' After arranging about shepherdesses, each amateur shepherd to have one, except the priest, who, according to Sancho's views, ought not to be associated with a lady ; but if the bache- . lor Sampson was inclined that way, why, his soul was at his own disposal. Then the knight begins to anticipate the ditties he and his associates would indite to the charms of their lady loves, when Sancho, mentally recurring to occupations more agreeable to his taste, and with which he was more at home, exclaims in a rapture, ' $\mathrm{O}$ ! what spoovs! What neat Wooden spoovs will I make when a shepherd!' An exclamation which he never, of course, could have made had he not been engaged in that business before. Then, like a sound philosopher, who only regards science and the arts in proportion as they are applied to the purposes of life, he instantly recurs to the use of spoons, and, very naturally to 
the agreeable visions they call up. "What crumbs! What cream! What olla-podridas! What stews we shall have!"

Having thus shown that the Knight of La Mancha's squire was, in the early part of his career, a manufacturer of spoons, the reader will at once concede the propriety of this reference to his labors; since he is, beyond controversy, the most famed character of the kind in print. But that is not all. There are other things in Cervantes which reviewers never dreamt of. It were an easy matter to show, but would be out of place here, that the celebrity of his great work is due chiefly to spoons ; for example, had he withheld from Sancho the penchant for handling them, the history of Qnixote might as well have been without the owner of Dapple ; and every body knows what an insipid affair it would have been then. From what but the free use of spoons were the jolly face and sly look of Sancho derived? To what else but their neglect was to be attributed the ghastly appearance of him of the Rueful Countenance? Silenus and a moving corpse!

Such are the wonders wrought by the Spoon: but, great as they appear, they are not the greatest. Had the knight lived in the manner of Sancho, he had never lost his wits ; and had the latter dieted as his master, he never would have had any. The moral of the romance is misunderstood. The author designed to inculcate this truth-that the proper use of a spoon can make a sensible man of a fool, and the neglect of it a fool of a sensible man! 
The Spoon is really the nucleus of the romancethe core on which the party colored threads of the story are wound. Indeed, the whole affair is nothing else than a mystic account of this useful little implement, and written by Cervantes, most likely to fulfill a vow made on account of the services it rendered him on some occasions of extreme distress-occasions, from the checkered scenes of his life, believed to have been of frequent occurrence.

These things, to be sure, do not stand up on the surface-they are not seen at a glance. Cervantes, in concealing them from readers whose obtuseness of intellect does not suspect them, or who will not take the trouble to look for them, imitated the conduct of his witty and ingenious countryman, Pedro Garcias, whose epitaph strangely announced that his soul lay under the slab. And there it did lay, without exciting the least curiosity from the crowds walking over it, until a poor and shrewd student of Salamanca, travelling that way, guessed the truth, disinterred, and joyfully carried home the Licentiate's soul in his pocket. But to leave such matters: As every person on earth loves a spoon, there are few who cannot relish an essay upon it; and all will admit its selection for a theme, if no proof of genius, is at least a strong indication of taste.

The Spoon is one of the first things wanted when we come into the world, and one of the last we part with before we go out. It is the companion of childhood, manhood, and age-the great nurse of mankind. It administers comfort to ladies when they 
'lay in,' and to every person before being 'laid out.' Without it, no baby takes pap; nor boys and girls porridge or soup; the man acquires strength by its aid, and it assists in prolonging the years of the old and infirm. In the hands of physicians, it drives sickness away; and when the angel of death comes at last, it soothes the last moments of many.

Its infuence is felt in every department of lifein manners, morals, and even in national characteristics. Associated almost as much with the sonl as the body, it seems equally to modify both. It is a healer of wounds, whether in the person or mind. What tempers has it not subdued-what passions allayed! For it is always called in after a broil to promote peace and good will. What evils, too, has it not extinguished which want has conceived and poverty planned! Hunger and haggard despair fly before it, while health and hilarity attend it! It is, and justly, a universal favorite-as well with the savage as the sage-with ladies and their maids-with children and their grandpapas.

What urchin has not felt more elastic when beholding his mother beating up eggs for plum-cake with a spoon; or stood by when with it she scraped out the bowl in which the pudding was made! And where is the youngster with 'a sweet tooth' that has not thrust it with delight into 'mush and molasses!' or with joy almost extatic made it dive into 'samp,' through an ocean of melted butter and sugar! As for grown people, it daily works the same wonders in them as it did in the Rev. Mr. Sampson when ap- 
plied by the hospitable hand of Mrs. Merriless. In barbarous and semi-barbarous countries, few meals are prepared without it, but in civilized life it is as regular an attendant at table as plates.

The moral influence of the spoon is remarkable. It preaches contentment, and fosters no pride. It enters the cottage and comforts those who are too poor to own either cottage or cot. It ascends into garrets, dives into cellars, and forces its way into prisons, where, like a Howard or Frye, it condoles with the children of sorrow. It is all things to all men, for it adapts itself to the circumstances of all. To the humble or poor, it appears in homely apparel ; to the rich and the proud, it shines forth in ivory and pearl-in silver and gold.

Some men talk about the 'social glass'-of the pleasures it imparts, the agreeable reminiscences it calls up ; but what are they, compared to those associated with the spoon? The former is selfishmen indulge in it by themselves; but the latter is the innocent companion of both sexes-of young and old. The glass too often destroys domestic joysloosens domestic ties; the spoon revives the one and strengthens the other. It gratifies a natural, the glass an artificial, appetite. The one imparts happiness to the abstemious, the other maddens the brain of the intemperate. Here sits an industrious laborer at his evening meal; he has reached home shivering with cold and faint with hunger; he sups the warm pottage his wife has prepared, and finds his heart strengthened, and his energies blessed. 
There carouses an acquaintance at the tavern; his eyes now rolling with the maniac's gaze, and now like an idiot's, fixed on vacancy. Reason has left her seat, and the character of the man is lost in that of the beast. Such are the different effects of the 'social glass' and the spoon.

A lover of domestic quiet, family jars cease in its presence; for unlike the mischief loving ladle, the spoon enters into no broils. An instrument of peace, it lends not itself to those illegitimate and unconjugal uses to which enraged housewives are said sometimes to put its taller associate. No! Instead of stirring up the caldron of family feuds, the gentle spoon soothes the boiling elements, and, in the pleasantest way imaginable, silences the squalling of infants, and the grumbling of older folks.

It took no part in an ancient fray between the scholars of Oxford and some Reverend companions of the Pope's Legate, on a feast or saint's day ; but the soup or rather the broth did. The peace loving spoon withdrew ere the fracas began. "And at that tyme was maister Edmunde of Abendon archbishoppe of Caunterbury, an holi man, in the twelff hundred yere of our Lorde and foure and thritti. And at that tyme come the legat Oter from Rome, and called a councelle of Bishoppes at London, and went from thens to Oxenford, to the Abbey of Osney. And as certeyn of the clerks come to speke with the legat, vppon Seynt Gregoryes day, one of the legats men cast hote broth vppon a scolore, and then come the clerkes first, and besett Osney, and slew one of the 
legats men, and the legat fled into the steple." $\left[P e^{-m}\right.$ ter Langtoff's Chronicle, Hearne's Glossary, vol. ii. 682.]

This quotation may serve as a little seasoning to the dish before the reader. If any one questions its pertinence, and that of others hereafter to be noticed, we beg to observe that what relates to the soup can hardly be foreign to the spoon.

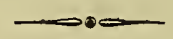

\section{CHAPTER II.}

The Spoon always an Object of Plunder-Border ThievesGolden Rule-Index of Human Condition-OOld English and other Salutations-Lip Worship-Spoons formerly Preachers of Temperance-Their Influence on Individual and National Character-Beef and Bouilli-Fat Men fined and Obesity revered-Steaks and Stews-Effects of Animal Food on Nations -War Speech of an English General-Greeks and TrojansSpoons of peculiar Antiquarian Value-Trick of AlexanderCurious use of Spoons, and Lessons derived from them-Their Influence in Politics and War-Procure Food as well as Cook it-Friends in need-Heir-looms.

The virtues of the spoon have in every age led men to covet it, and, to gratify their covetousness, to commit burglaries to obtain it. With the wicked, this is natural; for a silver spoon is a talisman-he who possesses one can never want. It is chiefly, however, such unfortunates as are not born with one in their mouths who thus attempt to supply what 
nature forgot. But horn and pewter spoons were not despised by respectable robbers of yore. In Maitland's "Complaynt against the Theivis of Liddisdail," we find them borne off from poor people's dwellings, along with bread, fowls, spinning apparatus, bed-clothes, shirts, \&c. The old leviers of black mail seized on every thing that was not 'too heavy or too hot' to be carried away.

Thay spuilye puir men of their pakis,

Thay leif them nocht on bed nor bakis;

Baith hen and cok,

With reil and rok,

The Lairdis Jok,

All with him takis.

Thay leif not spindel, spoone, nor speit,

Bed, bolster, blanket, sark, nor scheit.

Many a knife has committed murder, and forks have been guilty of felony; but what bad thing has the spoon ever done? Kidnapped in all ages, it never was known to return evil to its evil entreaters; on the contrary, it has blessed its greatest foes. Like the sun shining on the wicked and the good, this servant of man has been among all nations, kindreds, and tongues, a practical teacher of the Golden Rule-withholding its services from none, but feeding alike the thankless and the thankful. No implement has done more for man. Almost all others have been turned against him, but the spoon-never.

The spoon is an indicator of merit and of human condition. It is every where deemed an appropriate crest for the arms of an alderman, because every where hailed as the symbol of good cheer. A wooden or a pewter spoon, or one of tinned iron, is an 
emblem of an author, who seldom gets a better, unless he borrows it; a silver one, the symbol of a printer, who is generally "well to do ;" and a golden one, of a publisher, who alone in the book trade can afford to eat turtle. Of all indications of poverty, a broken pewter spoon is the most distressing-a proof of wretchedness extreme.

The implement is about the only one belonging to the kitchen that behaves well in the dining room. Its associate, the angry knife, sometimes wounds its master, and the sly fork occasionally pricks him, but the spoon is 'ever faithful,' and the 'most obedient of servants.' To these amiable qualities it is possible the very common expressions, "Your humble servant," "Your most obedient and faithful servant," may be allied; for it is a fact that these French forms of address were first introduced into English compliments and composition on an occasion when the spoon performed a royal part-at the marriage of Mary, daughter of Henry IV. of France. The usual British salutations before this were, "God keep you," "God be with you ;" and with country people, "How dost do?" accompanied often with a whack on the shoulder; and, if a woman, with a smack on the lips. (See Antiq. Repertory, iii. 43.)

Antiquarians inform us that kissing with a smack was a Roman practice; for the benefit of future Archæologists, an equally surprising fact may as well be mentioned of the Dutch, who actually relish other earthly comforts in a similar way! Whenever a glass or spoon leaves anything agreeable within 
their lips, the approving smack, it is said, invariably follows. This sharp and pleasant little sound is so inseparably associated with their ideas of the good things of this life, that it has become incorporated with their ordinary salntions. Their usual morning greeting is "Smaakelyk eeten!" So a southern Chinese salutes another by saying Yatan? Have you eaten your rice? In other words, have you handled your chopsticks or spoon?

The spoon is a fine symbol of complaisance. No one takes hold of it without pleasure, and many lay it down with regret. Its daily appearance at table is met with smiles, and every guest intimates his or her unalloyed joy by carrying it to their lips. In some countries it is so esteemed that when loaned it passes directly out of the mouth of the owner into that of the borrower. (See account of Esquimaux ladies at dinner, in the late voyages to the north.) Like the black stone at Mecca, it is polished with the lips of its admirers. A censorious world might stigmatize this as "lip worship," but it flows from the heart; or, at least, from the neighborhood of the heart, for, according to Chinese philosophy, the seat of the soul is in the centre of the stomach. So thought an old statesman and poet :

From thence she sends out those supplies

Which make us either stout or wise;

The strength of every other member

Is founded on your belly timber;

The qualms or raptures of your blood

Rise in proportion to your food;

And if you wonld improve your thought,

You must be fed as w ell as taught. 
Though with some an instrument of gluttony, the spoon was formerly a preacher of temperance; the lessons it taught being engraved as mottoes on the handle ; while for those on whom words made no impression, (and few who used it in the middle ages could read,) images of death and the devil were cut on the bowl! Plate $V$ has a figure of one of these curious inventions for enforcing moderation at meals-one on which is emblazoned a deatl's head! 'Think for a moment how could the most confirmed gourmand sin with such a tool! Why, the chef d'auvre of gastronomic fluids could not be conveyed to any man's stomach in excess by it, unless the owner of the stomach was blind. The most horrible of memento morii not only staring him in the face, but actually mixing with his food! If anything could subdue voracious appetites, one might suppose this would.

The spoon opens the mouth of every dumb person; and, what is sometimes as difficult to accomplish, it stops the most loquacious one. Its effects are exceedingly diversified. With most people, eating puts an end to speaking, according to the venerable precept, "Let your meat stop your mouth;" but some are more talkative at table than any where else. We remember an old lady remarkably taciturn except when handling a spoon. It was a key that unloosed her tongue. Every time she sipped coffee or tea, a remark dropped from her; but not a word ever came out till the spoon had first gone in; as if it carried permission to the imprisoned member to take a moment's exercise. 
Its influence is very observable on nations. It modifies their manners and customs, affects their arts, sciences, and manufactures ; gives tone to individual character, to modes of thought and action. Who does not know that the vivacity and other marked attributes of the French people are derived from the free use of the spoon? They are too wise to follow the example of their saturnine neighbors, in everlastingly using the knife and the fork. It is a fact too well known to need repetition here, that the differences in the temper and habits of the Briton and Gaul are to be traced to Roasts and Ragouts, to Beef and Bouilli.

The Celts and Gauls fined a fat man, and increased or diminished the penalty according to the size of his paunch-reversing the doctrines of India, where Rajahs are respected for their obesity-and of Southern Africa, where ladies are admired for the width of their waists, and their beauty determined by the hundred weight.

Steaks make a German or an Englishman portly and dull; stews, a Frenchman light and agile. On one side of the channel, fries render men heavy as dray horses; on the other, fricasees make them frisky as genets. It is the spoon that causes one people to be graceful in their persons and polite in their demeanor, and the want of it another ungainly in their movements and awkward in their compliments-that fits this people for natural teachers of dancing, and makes those persons incapable of appreciating the rudiments of personal accomplishments. So with 
other national characteristics. All may be traced more or less direct to the knife and the spoon.

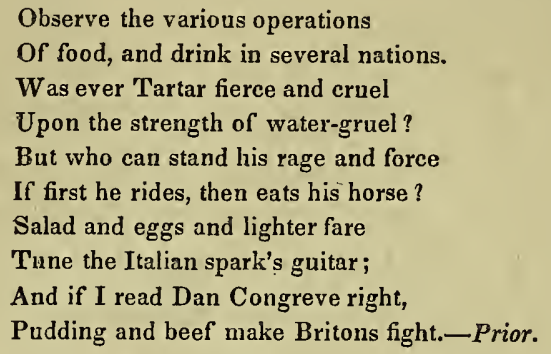

Howell says, 'while Englishmen drank only ale, they were strong, brawny, able men, and could draw an arrow an ell long; but when they fell to wine and beer, they are found to be much impaired in their strength and age.'

An old British commander thus addressed his troops on the eve of battle: "What a shame it would be to you, Englishmen, who feed upon beef and drink beer, to let those rascally Spaniards beat you, who eat nothing but oranges and lemons." The same intellectual gentleman we presume it was who supposed a well-known passage in Macbeth had reference to the dressing of a beef steak or mutton chop :

If it were done, when 'tis done, then 'twere well

It were done quickly.

Sir William Temple attributed the bravery of his countrymen to their carnivorous propensities. According to this doctrine, and it has many advocates, rice-eating Asiatics can never withstand European feeders on beef: those nations that excel others in killing cattle for food will generally be the most suc- 
cessful butchers of men-the most valiant eating the most bullocks. The principle is certainly illustrated in almost every page of ancient history-and the most in accounts of those nations the most knownas the Greeks, Carthaginians, and Romans. So in the present day-oppressed people are such as are confined to vegetable diet, as the Hindoos, the Irish, \&c. In the Iliad, spits, roasting fires, and boiling pots are about as common as spears, shields, or clubs: and enumeration of cattle, sheep, goats, and swine, as troops of men and horses. The Greek princes were their own butchers and cooks, and were often half broiled while preparing their dinners. But we don't read of Hector or his friends sweating like

Patroclus, who o'er the blazing fire

Heaps in a brazen vase three chines entire.

No! the people of Troy were unfortunately more chastened in their manners, and refined in their appetites, and hence compelled to yield to their savage and flesh eating invaders!

Spoons possess a high antiquarian interest, not merely as specimens of the arts, and indicative of the use of hot fluids in former times, but as bearing on the curious subject of human stature-on the question of the degeneracy of man's frame. Egyptian spoons of great antiquity are preserved in museums of Europe, and are of the same average size as those now in use; [see figures farther on;] proving in the clearest manner that people's mouths, between three and four thousand years ago, were of the same width and capacity as ours. If mummies, therefore, had 
never been drawn from the catacombs of the Nile, these little implements would have been sufficient to show that while the subjects of the Pharaohs surpassed other people in the magnitude of their works, their souls dwelt in bodies no larger than ours.

Ancient caldrons were often of enormous capacities, sometimes equaling a modern brewer's vat. This was on account of the large households of princes-their families, like Solomon's, consisting of hundreds and even thousands of officers and attendants ; but there is no record of the spoon having ever varied in its general dimensions. Had Alexander, when he wished to deceive posterity into a belief that his army was composed of giants, buried on each field of battle a few gross of spoons, capacious as good sized ladles, the deception would have been as likely to succeed as by his inhuming bridles and mangers for mammoth horses, and armor suitable for such men as Goliah of Gath, and the old King of Bashan.

Is it imagined existing ladles of a former world were possibly used as spoons, and therefore such reasoning is not conclusive? A little reflection will show the contrary; or if the reader will turn to Plate III, he will see it would be a very difficult matter to empty an ancient ladle, or simpulum, into the mouth, in consequence of the position of the handle; this being perpendicular to the mouth of the bowl; whereas in the spoon it is on a line or nearly so with it.

In how many ways does the spoon contribute to 
man's enjoyments! Besides its more appropriate business, it often assists in quite different matters. Its devotion is not confined to the mouth, nor to things for the mouth, but, like an anxious attendant, is ever ready to lend its assistance where it can. Most readers can call to mind numerous occasions on which the value of its presence was felt. Neighbor Windt can never get up the heels of his shoes till in place of his fingers he applies the shank of a spoon, and matches were never made in his house without tipping their ends in brimstone fused in another. Is a person faint? The spoon is called to revive him. Are you in pain? quoth the doctor, "three drops from this vial, in a tea-spoon full of syrup, will relieve you." You are restless? "Take these pills in a table-spoon full of. wine, and you'll soon be asleep." Infants suffer greatly in cutting their teeth, but by "champering a spoon," the gums are sooner cut through; and thus this devoted servant of our species kindly hastens the period when, in a more legitimate way, it can gratify little innocents.

When influenzas rage, what is the first act of attending disciples of Galen? To ask for a spoon, that with it they may press down the tongue to examine the fauces. In epidemic catarrhs, there is scarcely a house free from the disease, or a spoon from this service. Now, is it not remarkable that in afflictions of the mouth and throat the benign and sympathetic spoon should not only administer appropriate medicines, but be actually called in ere the 
nature of those medicines is determined! Its presence required by consulting physicians, as if fiom its familiarity with the patient, his habits and manner of life, and its acquaintance with the bronchial regions-its aid was indispensable!

It serves prince and peasant on some curious occasions. The part it performs in the coronation of kings will be noticed further on, but we may here notice how the poor derive from it a valuable lesson. Start not, gentle reader, at our announcing that spoons have long taught the children of penury to lay right in bed! Yes; and shown them the only way, in certain cases, by which either to get in or keep in-solving a very curious geometrical problem. The custom alluded to is said to be well known in soldiers' barracks, lodging houses for mendicants, in cheap boarding schools for boys, and wherever circumstances require four or more persons to sleep on one couch. It is obvious uniformity of position and movement, in such cases, is indispensable to individual repose.

When half a dozen spoons are laid out separateiy, they take up considerable room, but place them edgewise, bring up the mouth of one close to the back of the next, \&c. and the whole will form a compact mass. Just so with half a dozen tenants of one bed; if laid promiscuously, they could not find room; that is only obtained by placing themselves "spoon-fashion"-all turned one way and close fitted to each other. The oldest occupant regulates the positions and motions of his fellows. Having 
the privilege of first laying down, he adjusts himself to his own liking; drawing up his knees as far as he finds agreeable, he becomes a model or pattern to which those behind him must conform. No one can then "turn on t'other side," without general consent; and it is only when the chief gives the signal (by exclaiming "spoons,") that the interesting evolution takes place.

Spoons were formerly used to feed the nose as well as the mouth-snuff being conveyed in them to the nostrils instead of between the finger and thumbbut this will be illustrated by a cut on a future page. We have somewhere read of the implement performing the part of a linguist-interpreting between navigators and strange people. When other modes failed to make known the want of food, the sight of a spoon, accompanied with the usual movements in using it, instantly opened the understandings of savages, and saved Christian travellers from starvation.

Silver spoons have made their influence felt in the politics of nations. The enthusiasm of the people of England in supporting the cause of the parliament against Charles I. may be gathered from the contribution of the inhabitants of a single town to the republican cause. In London, enormous masses of plate were heaped up in Guildhall, the gift of the citizens. We select a few items from the list of donors named in the History and Antiquities of Great Yarmouth, [Norwich, 1772.]

"Thomas Goose, seven pieces of plate and two spoons.

"Robert Wakeman, 51 oz. of plate, at $5 \mathrm{~s}$. $4 \mathrm{~d}$. per oz. and nine spoons in coarse silver, weiging $14 \mathrm{oz}$. at $4 \mathrm{~s} .6 \mathrm{~d}$. per oz," 
[We leave it to modern smiths to distinguish between the "coarse" and "best." silver.]

“William Burton, 59 oz. plate, one spoon, best, and four coarse spoons and a bodkin.

"George England, $91 \mathrm{oz}$. and seven silver spoons.

"Robert Huntington, $158 \mathrm{oz}$. and one spoon.

"William Bridge, 10 pieces of plate and seven spoons; and at another time, $72 \mathrm{oz}$. and seven spoons.

"John Thompson, two cups and a spoon."

The above may serve as a commentary on the following lines from a contemporary poet, by whom the parliament is addressed :

Our plate, our coin, our jewels, and our rings,

Arms, ornaments, and all our precious things,

To you we brought as bountifully in,

As if they had old rusty horse-shoes been.

Butler, the champion of monarchy, as a matter of course turned this patriotic ardor into ridicule:

Did saints for this bring in their plate,

And crowd as if they came too late?

For when they thought the cause had need on't,

Happy was he that could be rid on't.

Did they coin $\mathrm{p}-\mathrm{p}-\mathrm{s}$, bowls and flagons,

Int' officers of horse and dragoons?

And into pikes and musqueteers,

Stamp beakers, cups, and porringers?

A thimble, bodkin, and a spoos,

Did start up living men as soon

As in the furnace they were thrown.-Hudibras, Canto ii.

Nor have pewter spoons been behind silver ones in freedom's cause. Few kitchen utensils have done more for national independence. Like those in the house of John Adams, they have been molded into bullets, and sent in haste to stay the stomachs of mercenary troops attempting to prey upon their owners. In the war of the revolution, when the spoons in New-York were used up, a set of men 
without the fear of God or the King before their eyes, pulled down the leaden statue of George in the Bowling Green, and fused him into balls. Then, as the royal officers professed to honor the king in their hearts, the rebels thought it right to send him into their bosoms. Here we see how spoons, though designed to convey victuals to the mouth, can of themselves effectually silence the cravings of hunger.

In another sense, pewter spoons have entered the field. Essentially of domestic habits, and brought up to wait on their owners at table, yet when a country family's provision has been spent, they have been known to go in quest of some. Putting on a new form, (being cast into "buck-shot,") they have left home, like Esau, "to take venison," and have generally returned (in the bodies of the game) with fresh supplies for the larder. Having done this, they have, in one or two instances, (when serving a backwoodsman,) resumed their previous occupation, (being recast,) and assisted to cook and serve up the animals they killed. But this is rarely the case, for rambling in the woods commonly puts an end to their household occupations.

In cities, silver spoons often leave home to raise means for purchasing provisions when the purse of their owner is emptied and his credit quite gone. Pledged for a loan, they remain in prison without murmuring till his circumstances revive and he redeems them from thraldom. Money lenders turn their backs on the poor man's knife and fork, but never refuse his silver spoons-their touching ap- 
peals cannot be resisted. Like those heroic Moravian Missionaries, who went into slavery to benefit perishing heathen, these well disposed little things repeatedly save Christian families from famishing by acting in a similar manner. After a prolonged absence, great is the joy on their arrival-then every one takes them by the hand and greets their return.

Thus the spoon contributes to man's joys in prosperity, and diminishes his sorrows when in pecuniary trouble. It is a friend that sticketh closer than a brother. Like a Grecian or Roman nurse, its labors cease not with the death of its master-it continues to serve him in his descendants. Made an heirloom, it bears his initials or his name, and is sent down to succeeding generations, a cherished memorial of the friendship that existed between them. 


\section{CHAPTER III.}

Proverb respecting Long Spoons-Attempt to define its origin-Fenale Costume-Trains, Steeple Caps, Fardingales and Ruffs-Extract from an old Sermon-Homity on DressEnormous cost of Ruffs-George Heriot-Oriental long. Spoons -Satan's Houschold-Other Proverbs-Conjurers-Mountebankes-Lotteries-Feats of the Spoon on the Stage-Curious Practice of Morris-dancers-Superstition of the Goths-Dryden -Gruel-Possets-Spoons doing duty as ferulas-Sir Thomas More-The Spoon or Spoon-meat typical of Infancy.

The spoon, as is well known to most readers, gave rise to a once celebrated proverb, indicative of the advances of sin and the lengths to which the wicked are led-“He wants a long spoon who sups with the devil." The saying is now nearly obsolete, but it was formerly, like the implement itself, in every one's mouth. Thus Chaucer, in the Squire's Tale :

What he answerd it nedeth not reherse;

Who can say bet than he, who can do werse

Whan he hath al wel said than he hath done.

Therfore behoveth him a fil long spone

That shal ete with a fend.

Shakespeare, in the Tempest, makes Stephano exclaim, on beholding Caliban, "Mercy! Mercy! This is a devil, and no monster; I'll leave him ; I have no long spoon." And in the Comedy of Errors, the whimsical mistakes occasioned by the resemblance of the twins to each other, led the parties to suppose Satan himself was in the perform- 
ance. Antipholus of Syracuse is invited by a female to dinner, his servant hints to him the character of the hostess :

Dromio.-Master, if you go, expect spoon-meat, or bespeak a long spoon. Ant.-Why, Dromio?

Dromio.-Marry, he must have a long spoon that must eat with the devil.

There was in Shakespeare's time a more substantial reason why those who supped with ladies as well as such as partook of Satan's hospitality, should have long spoons; and why ladies themselves should have been, as they actually were, furnished with them. "Indeed!" exclaims some female reader; "pray explain." Certainly, madam ; but before doing so, it is expedient to allude to something else.

From the times when primitive British ladies were clad in skins sewed together with sinews and pinned on the person with thorns, to those when AngloSaxon dames wore tunics and mufflers, and Norman females wrapped themselves in broidered mantles and copes, and thence to the present days, every age has been distinguished by innovations in costume, and of a very marked character. Norman fashions were succeeded in the fourteenth and fifteenth centuries by the English gown, bibs, aprons, and corsets. Immense trains were attached to the skirts of gowns. Horned and also steeple caps for the head made their appearance, thus lengthening both extremities of the person to a monstrous extent. A lady, on a visit of ceremony, is said to have sometimes been in the centre of a drawingroom, while the tail of her dress was still in the 
street. Chancer is severe on this and other parts of female dress. In the Parson's Tale, he rails at "the superfluitee of the foresaide gounes, trailing in the dong, and in the myre, on hors, and eke on foot." In Dunbar's Poems, they are represented as performing the part of a besom :

Sic fartingaillis on flaggis als fatt as quhailis

Fattit lyk fulis with hattis that littel availis;

And sic fowill tailis to sweip the calsay clene.

[Pocms by W. Dunbar, from the MS. of George Bannatyne. Perth, 1788, p. 52.]

Steeple caps towered about a yard above the heads which bore them, so that ladies in full dress could hardly pass throngh an ordinary door, or stand in a modern room. Queen Elizabeth, it is well known, carried her head pretty high, in more senses than one, but she had sometimes to bend. Visiting Burleigh, when he was laid up with the gout, she was much incommoded by her head-dress in entering his dwelling. As the stateman's servant conducted her through the door, he cantioned her to beware of the lintel, saying, "May it please your Highness to stoop." The haughty dame replied, she would not incline her body to the Spanish King, but on this occasion would bend to see his master. For specimens of steeple caps, see illustrations in current editions of Froissart, copied from illuminated MSS. particularly Isabella, wife of Edward I. entering Paris; the Dutchess of Montfort entering Nantes, and Philippa, consort of Edward III.

The sixteenth and part of the seventeenth century were characterized by long bodices, puffed sleeves, 
the famous fardingale, and celebrated ruff. The huge cylindrical petticoat was projected by hoops as much at the hips as at the feet, so that the wearer seemed as if she stood through an opening in the centre of a round table, the linen cover of which reached down to the ground, and upon which she could arrange a variety of apparatus, such as a lady's work-bag usually contains-strongly reminding one of Chinese pedlars of small wares, who carry about goods on a somewhat similar looking contrivance. "The great ladies at Genoa (observes Evelyn) go in horrible overgrown vertigals of whalebone, which being put about the waist of the lady, and full as broad on both sides as she can reach with her hands bear out her coats in such a manner that she ap. pears to be as broad as long." See a portrait of Anne of Denmark, wife of James I. usually founc ${ }^{2}$ in works on costume.

The stiff ruff round the neck sometimes project ed so far that a plumb-line dropped from its edge would nearly coincide with the periphery of the pet ticoat. At other times, it was pinned up round the ears, forming a fluted and inverted truncated cone or rather, it resembled the outer leaves of a rose protecting the blushing beauty within. Portraits of Queen Elizabeth exhibit both modes of wearing the ruff. A smaller kind was worn by men in like manner, as may be seen in portraits of Bacon, Dud ley, Sidney, Cecil, and others of that and the fol lowing age. See also Dutch portraits, of the sixteenth and seventeenth centuries, and illustrated 
works of those periods-the ruff is represented enormously thick and proportionally broad. Both it and the fardingale are noticed by Cervantes.

Few parts of female apparel excited more notice than ruffs, and on none were bestowed more attention and regard. Cambric was first imported into England, (from Cambray in Flanders, and hence its name,) for the purpose of making them, and numerous were the devices for forming and stiffening the plaits. About the year 1574, an invention of great merit, in the estimation of ladies, was made, since it rendered the ruff much more commodious to the wearer, and increased the facility of dressing and putting it in shape. This was the famous "poking stick" - a polished steel implement which, when heated, was used for stiffening and plaiting the starched frills. The ladies had cause to rejoice that "setting pins" (slips of whalebone, \&c. formerly concealed in the plaits in the manner of fans) were thus superseded. These uncomfortable adjuncts formed a species of chevaux de frise, enclosing the neck, and not only keeping other people, but in a manner themselves, at arms length. Ruffs were not unlike the Chinese cangue, a thick board like a table, resting on the shoulders of a criminal, his head being passed through a hole in the centre-a device often compared to "a frill or collar." It prevents the wearer from reaching his mouth, so that unless fed by his friends he would inevitably perish with hunger.

Now, it has doubtless already occurred to our fair querist that, however elegant and fashionable ruffs 
formerly were, they must have been extremely incommodious at meal times. It is manifest no lady could with an ordinary spoon convey food to her lips without crushing or otherwise spoiling the most cherished part of her attire. The result was, longhandled implements came into vogue, and were not disused till "setting-pins" and "poking sticks" were laid aside, and the dimensions of ruffs diminished.

For ladies' sakes, the following enumeration of fashionable articles of costume is taken from a sermon preached in the fourteenth century to worldly-minded misses: "Thus the devil farith with men and women: first, he stirreth them to pappe and pamper their flesh, desiring delicious meates and drinkes; and so they hop on the pillar of the devil's temptation, with their horns, locks, garlands of gold and rich pearls, cauls, fillets and wimples, and riddled gowns and rockets, colors, laces, jackes, paltockes, with their long crakowes; and thus the devil beareth them upon the pillar to teach them to fly above simple folk, and saith they shall not hurt themselves-but he lieth falsely, for unless they are as sorry therefore as ever they were glad, they shall leap down from the pillar into the pit of hell!" Horned caps were too conspicuous objects to escape the good father's censure. The wimple was a species of hood that covered the head, neck, and shoulders. Paltockes-doublets, and probably pantalettes; such as worn by Turkish females. Crakowes, long pointed shoes.

Of the homilies appointed by Queen Elizabeth to be read in churches, the one on excess of apparel 
has some warm denunciations against wimples, mufflers, head-bands, crisping pins, ladies mincing as they went, and nicely treading with their feet. The gentlemen catch it also, with their velvets, furred gowns, corked slippers, trim buskins, and the multitudes of changes of dress-one of this color, another of that, one for morning, another for afternoon, this in Spanish, that in the Turkish fashion, \&c. The evil had risen to such a height that "neither Almighty God by his word, nor godly and necessary laws, could stop it." "One spendeth his patrimony in pounces and cuts, another bestoweth more on a dancing shirt than might suffice to buy apparel for his whole body. Some hang their revenues about their necks, ruffling with their ruffs!" All the world knows immense wealth, in the shape of jewels, is often pendant from a lady's neck, but few persons are aware that gentlemen formerly laid out fortunes on frills, and had peculiar shirts to dance in.

George Heriot, goldsmith to James I. is figured with a ruff consisting of plaits piled one over another, the whole being at least six inches thick, and projecting in proportion. He never could have conveniently fed himself with "cock-a-leekie," or "crowdy," the favorite dishes of King Jamie, with anything like a modern spoon, without deranging if not defiling his frill. Yet his and his master's were of moderate dimensions compared with those of the gallants of their days.

Long spoons are common with the Turks, Persians, and most Asiatics. They are mentioned by 
old travellers as "reaching a great way." The proverb associated with them no doubt arose from the primitive custom, still prevalent over the greater part of the earth, of the inmates of a house eating out of one dish. The tables on this account approaching a circular form, so as to give every individual an equal chance at the provision; like the knights at Arthur's Round Table. In large households, the tables were necessarily made in proportion, and as the dish was placed at the centre, the implements were adapted to reach it without rising. An idea has always prevailed that Satan's household never was a small one; spoons therefore much longer than common were supposed to be required by those invited to a seat at his table.

Other proverbs are connected with the subject. Henry IV. quoted one, when rebuked for his clemency to his foes-"More flies are caught by a spoon-full of honey than with a hogshead of vinegar." Perhaps the best description of a vain-glorious person is one in which he is represented as taking in praise like porridge, and "licking the spoon!"

Silver spoons, almost as much as anything else, afforded employment to conjurers and wise women of yore. Frequently stolen, their disconsolate owners had recourse to rustic oracles, who, with 'wand,' 'magic mirror,' 'key and book,' 'sieve and sheers,' or other cabalistic implements, found out the rogues. Sometimes the more learned professors of occult sciences were employed-men who consulted the 
stars on the fate of kingdoms, stray cattle, lost keys, and goods of every description and value.

They'd search a planet's house to know

Who broke and robbed a house below ;

Examine Venus and the moon,

Who stole a thimble or a spoon.-Hudibras, Canto 1.

Another class of men, whose glory has also departed, found a source of profit in spoons, viz.: Mountebanks, who were originally travelling venders of physic-a species of merchandise associated with rather unpleasant ideas-one ill adapted to form the staple of a lucrative trade. But, shrewd and observing, the itinerant quack knew the weak points of the species, and that to succeed he had only to keep his customers in good humor. Like a nurse coaxing sick children into love with the doctor's prescription, he tickled his hearers with the wonders his nostrums had wrought, and sold pills out of the same package for every complaint of man or beast. As people, however, are not always sick, he reminded them that they were daily in danger of being so ; and hence the wisdom of buying pills which not only removed disease but prevented its approach. In the seventeenth and eighteenth centuries, he added to his stock various light articles, as tapes, rings, ribbons, bodkins, scissors, spoons, knives, razors, tea-pots, trays, calicoes, and eventually introduced them in lotteries-expatiating on their superior qualities with a fluency which rivaled that of 'Kikero'-as a country pedagogue of our acquaintance insists on pronouncing the name of the Roman orator. 
Chap. III.] Grecian Charlatans-Hasty Pudding.

The poets of the last century often complimented these amusing artists, as Gay in his Sixth Pastoral:

The mountebank now treads the stage and sells

His pills, his balsams, and his ague spells;

Of lotteries, next with tuneful note he told,

Where silver spoons were won, and rings of gold.

The same gentry were very numerous in ancient Greece and Rome, and quite as clever as their present representatives. They dealt in trinkets and small wares, whose virtues were fully equal to modern ones. Eudamus, mentioned by Aristophanes, peddled finger-rings, for protecting the wearers from the bite of serpents or other venomous animals! Like recent artists of the same profession, he probably sold razors so sharp as would shave sleeping cats without wakening them, and spoons which rendered loathsome food pleasant, and poisoned food innocuous.

Modern mountebanks sometimes wound up the business of a lottery with general satisfaction, by providing fiom two to six bowls of hasty pudding, to partake of which an equal number of their patrons were invited to step on the stage. The food was scalding hot, and being retained in wooden bowls lost little of its heat ere passed to its destination. He who transmitted the contents of one bowl to his stomach in the shortest time was the victor, and bore off the prize; which was sometimes the spoon he had used. When every thing was prepared, the contest began on a signal given by the generous provider of the feast, and instantly accompanied with 
acclamations of the bystanders. The witty remarks of Mr. Merryman caused roars of laughter to become, like approaching thunder, londer and louder, until the rain descended, and the faces of the multitudes were fairly washed in their own tears. Before the performers half finished the task, their visages acquired the temperature and color of fire, in spite of streams of perspiration with which they were flooded.

This employment of the spoon was at one time so common as to have given rise to the soubriquet by which the principal performer was, and still is, distinguished-Jean Potage in France-Jack Pudding in England.

Here we see the spoon taking an active part in the public sports of the people, as well as in furthering their private pleasures. It entered into an innocent contest, which the knife or the sword never did. It achieved a bloodless conquest, and as an emblem of victory was often stuck on one side of the hat, by way of cockade. And let not the disciples of Chesterfield sneer at these rustic entertainments of ignorant times, for the effects on both actors and spectators were more beneficial in shaking off the gross humors of the system than cart loads of physic or wagon loads of sermons.

The spoon in another respect assisted old charlatans, and in that part of their performances most interesting to themselves and trying to spectatorsviz. in making the collection. The morris dancer, at the close of every act, put a large spoon or ladle 
in the mouth of the hobby-horse and made it career round the ring to solicit donations, when we may suppose few could resist the moving appeal. [See Douce's Illustrations of Shakespcare.]

The caldron and ladle have been employed in forbidden matters. Witches made 'hell broth' in - one, and stirred up the ingredients with the othermaking the gruel thick and slab-but the food entered no mortal stomach, and hence no mortal spoon was wanted. This may be inferred from older writers than Shakespeare-from Saxo Grammaticus and Olaus Magnus. They tell us about the practices of 'women witches of the North, where the devil truly hath his seat'-of the 'gruel' and 'earthen pot wherein the juices, herbs, worms and entrails' were boiled, \&c. but not a whisper about the spoon. Eventually the law of nature taught the Goths to detest devils and their dams, for it often happened that famines ensued when men obeyed them: 'birds and beasts forsook the woods, and fish the waters, and would not come back again [to be eaten] until such time as the Divine Majesty was pacified by prayers and benedictions of the sacred clergy.' So says the Reverend Archbishop of Upsal.

In satirical writings, allusions to spoon-meats were formerly common. When a passionate combatant had no other resource, he too often vented his wrath in gross personalities. Thus Dryden: 'Go back to where thy infancy began, eat pap and spoon-meats ;' or when a fling was made at people's diet, as in the Scornful Lady of Beaumont and Fletcher: 'Faith, 
sir, here are no oats to be got, unless you'l have 'em in porredge; the people are so given to spoon-meats.' A similar allusion to oat-meal gruel is made by $\mathrm{Du}$ Bartas :

And in a dish, for want of plate or glass, Sups oaten drink instead of hippocras.

In the sixteenth and seventeenth centuries oat-meal gruel constituted the regular breakfast and supper of children. Dryden has an allusion to it in the 'Wild Gallant' :- Boy: These last three weeks I have almost forgot what my teeth were made for. Last night good Mrs. Bibber took pity on me, and crammed me a mess of gruel with the children, and I popt and popt my spoon three or four times to my mouth before I could find the way to it.'

If the spoon was the first thing wanted in a morning, it was often the last thing laid aside at night; for when youngsters broke their fast with porridge, old people wound up the day's labor with posset,-a hot mixture of milk and mulled wine, and frequently taken in bed. The custom is repeatedly mentioned in old writers. Page promised Falstaff a posset, and Mrs. Quickly cheered Rugby with the hopes of another. Lady Macbeth drugged the posset of Duncan's grooms. Thomas Heywood, a contemporary of Shakespeare notices the custom: "Thou shalt be welcome to beef and bacon, and perhaps a bag pudding; and my daughter Nell shall pop a posset upon thee when thou goest to bed."

Besides feeding boys and girls, the spoon has been known to remind them when they do ill, its 
bowl being now and then applied to their pates, to teach them better manners. Among refined people or with mild housewives, this of course never occurs; but passionate cooks, when teased by young impertinents, seldom stop to reflect on the impropriety of using the same inplement to baste a boy's head and a roasting pig. In country parts this practice is probably more frequent than in cities, one thing there being often necessarily put to many uses. Like a faithful nurse, the spoon goes out of its way to benefit young folks by performing duties towards them that do not belong to it.

In some regions, poor people are not over-nice in their tastes-it's a merciful dispensation they are not. When the Highland hostess took her son's cap off his head, and immediately boiled in it a pudding for Sam. Johnson's dinner, she made the most of her resources, did the best her limited stock of dry goods would permit, and displayed as much ingenuity in the application of an old thing to a new purpose, as one half of those do who secure their inventions by patents. There is no doubt that such a lady, when busily engaged in making "stirabout" for her family, would hasten the movements of a desidiose boy by applying the implement she was wielding to his sconce, as well as by threatening to withhold the contents of the kettle from his lips. To be sure, such a practice is not very cleanly; but what can a country matron in like circumstances do? She cannot leave the porridge to "burn" or " boil over," in order to seek a suitable rod; if she 
did, in all probability the individual for whose benefit it was sought, would be non est inventus when she returned.

During the fierce contests between the advocates of faith and the champions of works, in the sixteenth and seventeenth centuries, the spoon was sometimes introduced. On one occasion it proved a powerful weapon in the hands of Sir Thomas More. See how skillfully he wields it:- "I would wene one sponeful of good works should no more kill $\mathrm{y}^{\mathrm{e}}$ soule, then a potager of good wurts should kill and destroi $\mathrm{y}^{\mathrm{e}}$ bodie." Wurts is the old name for unfermented beer-a sweet infusion of malt-and is an aperient. This was an argument ad hominum, or rather ad stomachus. In it the Chancellor administered, and in a very quiet way, a medicine that could not help moving their bowels; and it did move them-for those whom he thus addressed at length slew him. But such occasions are not the only ones where the spoon was associated with religious controversies or ceremonies, as the sequel of this essay will show.

The spoon, or 'spoon meat,' and 'strong meat,' have ever been typical of infancy and manhoodof weak and vigorous intellects. Paul tells the Hebrews they could only digest pap or spoon meats of children, instead of the strong food of men. "Ye have need of milk, and not of strong meat. Every one that useth milk is a babe, but strong meat belongeth to them that are of full age." Solomon has the same idea: it is in fact common as the spoon. 


\section{CHAPTER IV.}

Heraldic Emblems-The Spoon neglected-Families of Spooners-Dutch Coat of Arms-Crest for Bishops-Warriors -Punishment of Death-Discontented People subdued by the Spoon-Peace made by it lasting-A Teacher of Military Tactics-Waterloo-Manual Exercise-The Spoon once a Side-Arm-Ancient Tenures-Curious Deed of Land-Bishop of Exeter-Sheep-Walk and Wooden Spoon-Tcars collected by Spoons-Heaven opened by them-Property given to the Church-Mahommedans use Spoons in Paradise-Wash-Basin - Rebuke and Malediction.

Looking over some works on Heraldry, we were surprised at the multitude of culinary utensils adopted into that 'heavenly science,' as one of its professors calls it. As we proceeded, the reason became plain; for everything eatable, whether fish, flesh, or vegetable, being portrayed on escutcheons or crests, nothing was more natural than to introduce apparatus for cooking. As a symbol for beef, veal, mutton, lamb, pork, or venison, a gentleman selected for his crest, (as his palate preferred one dish or another) a bull or cow, a calf, a sheep, or goat, a lamb, boar, or stag. Those who lived more delicately chose a fowl, hare, or rabbit;-others, pheasants, partridges, pigeons, snipe, quails, wild ducks, geese, herons, and every kind of game. Such as loved fish, selected perch, pike, flounders, salmon, trout, and so on, up to sturgeons and dol- 
phins. Some had painted on their armorial ensigns, cockles, muscles, crabs, lobsters, and turtles. Those who relished vegetable diet, had sheafs of barley, rye, and wheat, beans, peas, asparagus, celery, turnips, cabbages. People fond of pies and desserts, had apples, pears, pomegranates, cherries, and grapes; and such as had more pleasure in handling the tumbler than the knife or spoon, selected for their crests, barrels [for beer], urns or vases [for wine], drinking cups, horns, goblets, mazars, \&c.

Of devices taken from kitchen paraphernalia, we cannot name half; here are a few: The hearth and fire, being essential for preparing dinner, often occur; so do torches to light the fire, billets of wood to feed and bellows to blow it. A spit to roast meat, and sometimes the roast on it. Fire-dogs or andirons, caldrons, skewers and flesh-hooks. (Heads, limbs, and joints of animals, ready for the spit or kettle, are quite common.) Colanders, watering-pots, cleavers, carving-knives, plates and dishes, salts, cups and tankards. Stools to sit on, tables to eat off, hand-bells to call waiters, buckets of water, basins and ewers, to wash after dinner; combs to dress the hair before sitting down, scissors to trim the beard, and caps to place on the head.

"Well, but where is the spoon?" To tell the truth, we have not been able to find it! A disgrace to the science of heraldry it is not emblazoned, or if it be, it has escaped our notice. The ingrates! Or, were they ashamed of adopting it to conceal 
their love of spoon meats? As if the world perw ceived not their design in concealing a round of beef under the figure of an ox, a chine of pork under a boar, a haunch of venison under a fat buck, a loin of veal under a calf-or as if the reverend gentleman who adopted "two shin-bones" for his crest, could by such an affectation of abstinence hide from a prying world his attachment to marrow and strong broth. [See Kent's Grammar of Heraldry, Lond. 1724, and also Guillim, where the above "devices," and hundreds more, may be found.]

There might be some excuse for Messrs. Fish, Flour, Bull, Bacon, Cook, Sprat, Drake, Taylor, Miller, Smith, Potts, Sadler, Wheeler, Fisher, Drinker, Baker, Carter, and others, rejecting from their coats of arms the object of our research; but surely the ancient and honorable families of the Spooners should have known better. They, at least, might have had the grace to acknowledge and adopt the implement from which their patronymic is derived. What could have been more proper? But alas! the earth is as full of pride as ingratitude, and many besides the Spooners are indifferent about inquiring into the condition and deeds of their ancestors.

In an ancient and imperfectly depicted coat of arms, the supporters are a man and a woman : one flourishes what appears a ladle, and the other holds something like a spoon; but Guillim, or some one else, explains the hieroglyphics in a different manner. With this exception, the arms of an old Dutch 
family come nearest the mark. Their crest was a Spoonbill, the most singular looking of European birds, and a native of Holland; but whether it was selected on account of its name, the form of its mouth, or the length of its neck, we are not informed. If the gentleman who chose it was a ravenous feeder on soups, and a believer in the doctrine that the pleasures of eating and drinking are proportioned to the length of the channel through which food reaches the stomach, his heraldic ingenuity surpassed that of any gourmand on record; that is, unless the musician mentioned by Aulus Gellius adopted it as an armorial ensign, which is not unlikely, since he used to wish for a neck as long as a crane, that he might longer enjoy the victuals he ate.

As an heraldic device, the Spoon is infinitely more becoming Christian men than spears, daggers, bows and arrows, catapults, hatchets, clubs, knives, and other murderous weapons, which knights and even bishops sport on their plate and the panels of their carriages. To church dignitaries it seems peculiarly appropriate-a symbol of benevolence, of a disposition "to feed the hungry." Charity, however, has always been at a discount, and the spoon, as its emblem, is neglected by heralds and bishops.

O, that warriors would adopt it ! It would be consistent with sentiments many of them affect. Besides, the times are rapidly approaching when conquest in battle-the subjugation of nations by brute force-will no longer make a hero; when people cannot be treated by their rulers like cattle, 




SMITHSONIAN INSTITUTION LIBRARIES

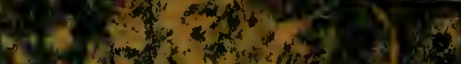

96.

(1) - the

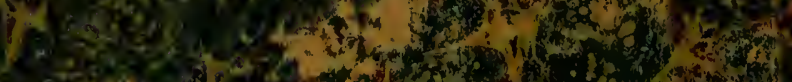

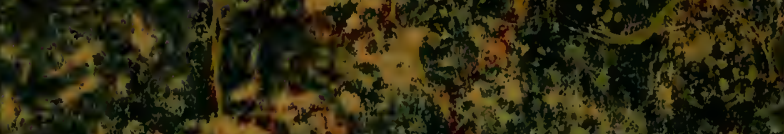

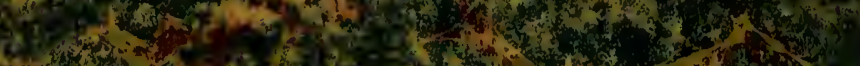

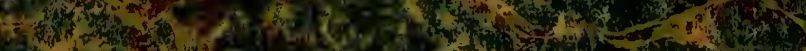

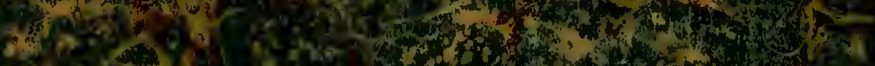

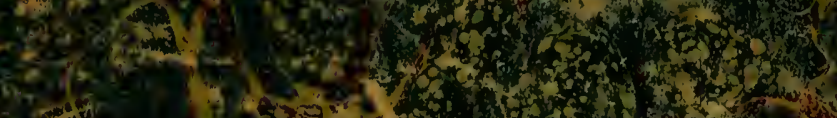

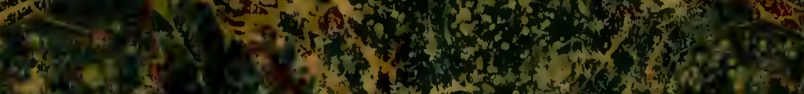

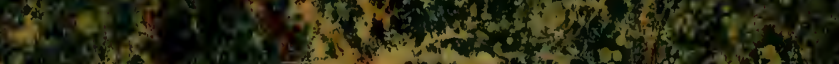

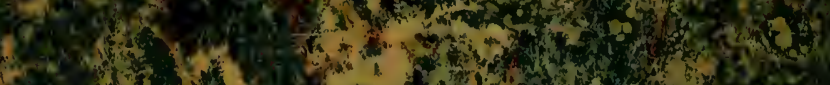

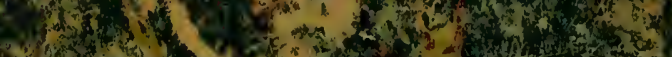
150.

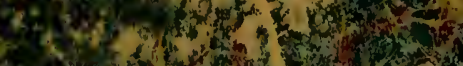

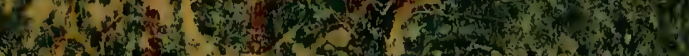

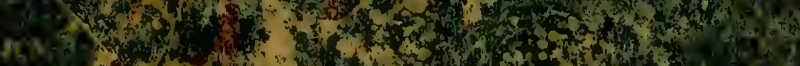

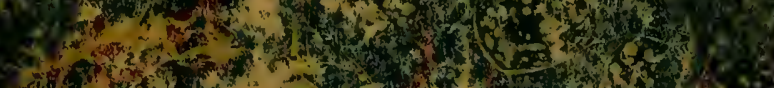

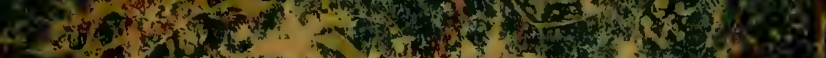

2. 3 (2)

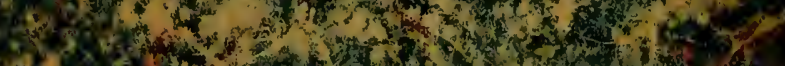

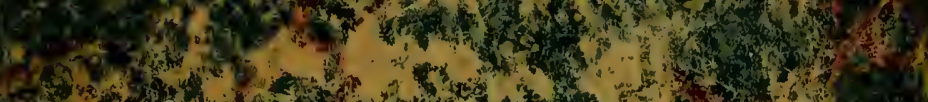
20.4.

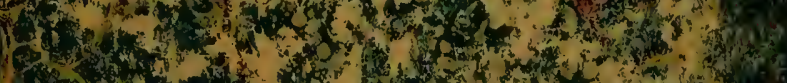

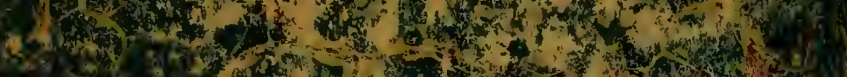

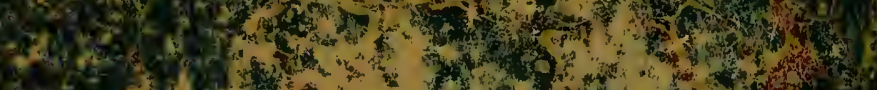

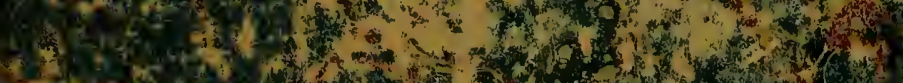

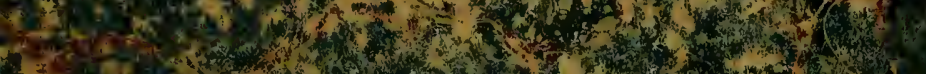

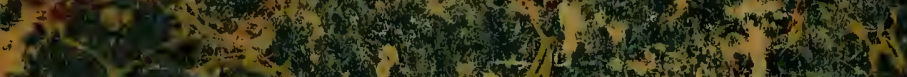

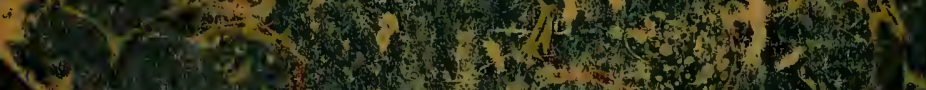
(2)

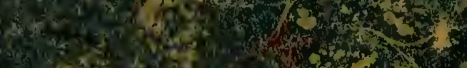
astions $x^{2} x^{2}$

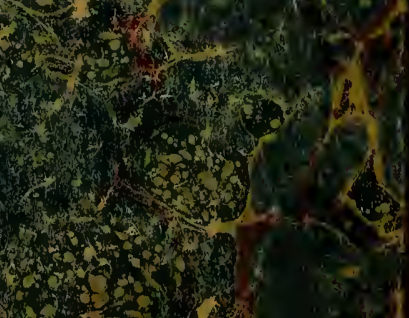

